\title{
Urgencia de la Bioética ante la Biotecnología: ¿Cómo identificar un ser humano unicelular?
}

\author{
María Alejandra Carrasco \\ FACULTAD DE FILOSOFÍA \\ PONTIFICIA UNIVERSIDAD CATÓLICA DE CHILE \\ Patricio Ventura-Juncá \\ CENTRO DE BIOÉTICA \\ PONTIFICIA UNIVERSIDAD CATÓLICA DE CHILE
}

Los grandes avances de la ciencia y la biotecnología presionan de manera creciente a la bioética para que tome una posición respecto de estas investigaciones, particularmente si sus aplicaciones podrían significar una violación a la dignidad humana. La Iglesia Católica reconoce esta urgencia cuando, en palabras de Benedicto XVI, dice: «En la actualidad, la bioética es un campo prioritario y crucial en la lucha cultural entre el absolutismo de la técnica y la responsabilidad moral, y en el que está en juego la posibilidad de un desastre humano e integral. Éste es un ámbito muy delicado y decisivo, donde se plantea con toda su fuerza dramática la cuestión fundamental: si el hombre es un producto de sí mismo o si depende de Dios» ${ }^{1}$. Y hoy nos encontramos frente a un caso paradigmático de esta encrucijada: los progresos biotecnológicos permiten producir artificialmente organismos (incluyendo a organismos bumanos, i.e. personas) a través de técnicas distintas a la fecundación, y manipularlos desde el momento mismo en que se constituyen. No obstante, la ciencia aún no tiene criterios ciertos para identificar, en estos casos, cuándo hay verdaderamente un organismo humano unicelular (el equivalente a un cigoto ge-

\footnotetext{
Benedicto XVI en Caritas in Veritate, 74. Ver también Juan Pablo II: Discurso en el Instituto de Bioética del Sagrado Corazón, 17 de febrero, 1996, 2; donde señala: «[La bioética] tiene el deber de indicar al mundo de la medicina, de la política, de la economía y de la sociedad en su conjunto, la orientación moral que se ha de imprimir a la actividad humana y al proyecto futuro» (citado por F. Chomali, Bioética. El valor de la vida bumana a la luz de la razón y la fe (El Mercurio-Aguilar; Santiago 2009), p. 31.
} 
nerado por fecundación) o cuándo aquello manipulado es sólo una célula -y en cuanto tal, sin objeción moral para experimentar con ella. Esto es lo que pasa, por ejemplo, con la clonación, en la que la ciencia no ha podido todavía discernir en qué momento exacto la célula intervenida comienza a ser un organismo.

El problema, naturalmente, se vuelve urgente cuando estas técnicas empiezan a ser aplicadas en seres humanos. En la Instrucción Dignitas Personae la Iglesia reconoce explícitamente la dignidad del ser humano desde el instante de su concepción. «La realidad del ser humano -afirma- a través de toda su vida, antes y después del nacimiento, no permite que se le atribuya ni un cambio de naturaleza ni una gradación de valor moral ... El embrión humano, por tanto, tiene, desde el principio, la dignidad de la persona» ${ }^{2}$. Y lo mismo se aplica a los embriones in vitro: «Los embriones humanos obtenidos in vitro son seres humanos y sujetos de derechos: su dignidad y su derecho a la vida deben ser respetados desde el primer momento de su existencia» ${ }^{3}$. Por extensión, el embrión producido de modo distinto a la fecundación poseerá también esa misma dignidad. ¿Pero cuándo estamos frente a un embrión producido de este modo? Ésa es la pregunta acuciante en la actualidad. Y aunque la ciencia no tenga todavía respuestas claras, la bioética, que es por definición una «disciplina interdisciplinan», junto a la vertiente científica tiene también una filosófica y, cuando se incluye el aspecto religioso, otra teológica; y es esta triple perspectiva la que permite, en estas situaciones inciertas, ofrecer al menos un marco de referencia para orientar y dar respuestas racionalmente justificadas a problemas que aún no están científicamente resueltos, pero que por la relevancia de sus aplicaciones obligan a tomar decisiones inmediatas en el orden moral.

Ahora bien, la bioética debe basar sus juicios en evidencias empíricas consistentes. Durante los siglos en que se desconocía la información biológica sobre la generación de un nuevo ser humano, el pensamiento católico participó de las diferentes teorías elaboradas por biólogos y filósofos, las cuales tenían muchas veces un carácter imaginativo-especulativo. Refiriéndose al inicio de la vida Santo Tomás pensaba que el alma debía ser infundida en una materia «idónea», diciendo que «la sustancia intelectual no puede unirse como forma a lo elemental» y «el alma es el acto del cuerpo organizado» (Suma Contra Gentiles II,89). En esa época el

2 Congregación para la Doctrina de la Fe: Instrucción Dignitas Personae, 2008, 5.

3 Congregación para la Doctrina de la Fe: Instrucción Donum Vitae, 1987, 5. 
conocimiento biológico respecto del inicio de la vida era inexistente y por ello el Aquinate afirmó que, como el alma no podía unirse a un elemento simple como sería el semen o el flujo menstrual, existiría la llamada animación retardada (S Th I q76 a3 s3; S Th.1, q118), i.e. la vida humana no empezaría en la fecundación sino en algún momento posterior a ésta. Esta carencia en el conocimiento científico lo llevó a decir -lo que hoy en día escandaliza a muchos- que el aborto no equivalía a un asesinato en los primeros estadios del embarazo. Sin embargo la situación actual de la ciencia es distinta, y ya hay evidencia consistente respecto del inicio de la vida en la fecundación; por lo que el razonamiento del Aquinate, cuya premisa mayor sigue siendo válida (el alma sólo puede ser albergada en una materia con una disposición y organización apropiadas), llegaría a una conclusión distinta.

Apoyadas entonces sobre la información biológica consistente, la filosofía y la teología tienen que analizar, a veces en forma apremiante, hasta qué punto las aplicaciones de los avances científicos -que no son siempre «buenas» para la humanidad ni respetuosas de su dignidad- deben ser promovidas o rechazadas. Éste es el objeto del presente artículo, que saca a luz un problema crucial para la bioética contemporánea, y el que progresivamente irá aumentando en relevancia.

Hace algunos años la clonación de la oveja Dolly sorprendió al mundo entero. La producción de un nuevo organismo a través de la técnica de la Transferencia Nuclear o SCNT («Somatic Cell Nuclear Transfen»), que en nada se asemeja a la fecundación, puso en el primer plano de discusión la pregunta respecto de cuándo comienza a existir un nuevo organismo producido de este modo. Los foros internacionales del más alto nivel, reflejando la trascendencia ética y antropológica de esta cuestión, han reclamado ya la urgencia de dilucidar en qué momento exacto se está en presencia de un nuevo organismo bumano unicelular, un miembro de nuestra especie que en el mismísimo instante de su constitución podría ser instrumentalizado y desechado para fines o intereses particulares ${ }^{4}$.

4 «Reconocemos que los aspectos éticos que surgen del rápido avance de la ciencia y de sus aplicaciones tecnológicas deben ser examinados con el debido respeto a la dignidad de la persona humana y el respeto y la observancia universal a los derechos humanos y sus libertades fundamentales», Declaración Universal sobre Bioética y Derechos Humanos de la Unesco, adoptada por aclamación el 19 de octubre del 2005 en la XXXIII sesión de la Conferencia General de la Unesco. (Salvo que se explicite lo contrario, todas las traducciones serán nuestras). 
El problema se acentuó con el descubrimiento de las células madres embrionarias (CME) y sus revolucionarias posibilidades terapéuticas, por al fuerte impulso que se produjo en la investigación con embriones humanos. Surgieron entonces, desde los grupos pro-vida, propuestas para crear CME sin la manipulación ni el riesgo siquiera de producir embriones ${ }^{5}$. Vale decir, aprovechar sus extraordinarias ventajas terapéuticas pero sin pagar el costo de una vida humana. En el año 2004 se propuso un procedimiento para obtener CME que parecía cumplir estas condiciones (la llamada ANT-OAR, que explicaremos más adelante) y que dio pie para un interesante debate entre expertos que defienden la vida humana desde su inicio. Aunque este método podría estar ya científicamente superado, la discusión propiciada será nuestro instrumento de análisis para entrar en las complejidades de este tema, puesto que ilustra nítidamente las preguntas fundamentales que la bioética debe responder frente a los problemas cada vez más complejos que con vertiginosa rapidez la biotecnología le presenta.

Una de esas preguntas, pero que no se abordará en este trabajo, se refiere a la definición de persona o desde cuándo el organismo humano comienza a ser persona, sujeto de dignidad y derecho inalienable a la vida. El inicio de la vida humana, desde una perspectiva biológica, siempre se ha entendido como el comienzo de un nuevo organismo ${ }^{6}$. En lenguaje filosófico se habla de un nuevo ser humano, puesto que es un nuevo ser vivo perteneciente a la especie humana. Pero lo que ahora se disputa es si basta ser organismo humano para ser persona. Según la antropología cristiana -y no solamente cristiana- evidentemente sí basta, ya que ese «organismo humano» comienza, desde su constitución, un proceso de crecimiento gradual, de desarrollo continuo, que no tiene ningún instante biológica o metafísicamente relevante como para decir que allí deja de ser una cosa para transformarse en otra. Sin embargo un gran número

5 En estricto rigor, sólo se debería hablar de CME cuando éstas ya han sido extraídas del embrión y cultivadas in vitro, o producidas por alguna otra vía. Mientras se encuentran dentro del embrión, se las debería llamar simplemente «células pluripotenciales». No obstante, en el lenguaje habitual no siempre se hace la distinción entre ambas.

6 Hablar de «organismo humano» responde a la perspectiva propiamente científica (cf. S. GILBERT, «Fertilization: Beginning a New Organism», en Developmental Biology, $8^{\text {th }}$ Edition Sinauer Associates Inc., 2006); mientras que la relevancia de ser o no «persona» es un tema de la filosofía y la teología. A pesar de que en este artículo usaremos mayormente el término «organismo humano» o simplemente «organismo», conviene, ya en la introducción, establecer que la razón última por la que la bioética se ocupa de este tema es el respeto a la persona. 
de científicos y filósofos contemporáneos, principalmente partidarios del aborto y en busca de su justificación, sí identifican algún instante en ese proceso de crecimiento gradual como el «comienzo» de una persona, recién entonces sujeto de dignidad. Para la Iglesia Católica en este punto no hay duda: todo organismo humano, en cualquier etapa de su desarrollo, es persona ${ }^{7}$.

Otra de las preguntas, que es en la que nos centraremos, es la que se refiere al reconocimiento del inicio de la vida de un nuevo organismo humano cuando ha sido producido artificialmente por algún medio distinto a la fecundación. Comenzaremos, en la primera sección, con definiciones científicas imprescindibles para entender el debate. Ya en la segunda expondremos los criterios que desde la ciencia se han propuesto para identificar a un nuevo ser humano en su etapa unicelular, y el debate que produjo la propuesta de la ANT-OAR para obtener CME sin violar la dignidad de ningún ser humano. Aquí se verá cómo la discusión fue aumentando en complejidad y requirió complementar la perspectiva científica con la de la filosofía. En la tercera sección avanzaremos en una posible dilucidación de criterios para identificar a un ser humano unicelular producido por este tipo de técnicas artificiales, exponiendo la dificultad metafísica con que nos encontramos para validar los índices propuestos; pero constatando también la urgencia ética de tomar una postura al respecto. Finalmente, presentaremos nuestra propia posición y el esbozo de un marco de referencia que, reuniendo las perspectivas científica, filosófica y teológica, da ciertos criterios que permitirían orientarse en esta imprescindible toma de decisiones.

\section{Precisiones conceptuales}

Para comprender la necesidad de encontrar nuevos criterios que determinen la existencia de un organismo humano, hay que explicar o precisar algunos conceptos biológicos claves para este problema. Comenzaremos con el de organismo; luego el de clonación, que fue el que puso el tema del desde cuándo hay un organismo si éste se ha producido por esta vía; en tercer lugar el de las CME, que dio urgencia a esta discusión; y terminaremos explicando la técnica ANT-OAR, la que utilizaremos como instrumento de análisis para mostrar las diversas aristas de este tema y alcanzar conclusiones prácticas y generales.

7 Cf. Declaración De abortu procurato, 18 de noviembre de 1974, 12 y 13; Encíclica Evangelium Vitae, 1995, 60, o Dignitas Personae, 2008, 5. 


\subsection{Definición general de organismo}

Hasta hace pocas décadas, previo a los avances tecnológicos contemporáneos y cuando sólo existían vivientes naturales, bastaba como índice para identificar una unidad orgánica su capacidad de realizar las operaciones vegetativas de nutrición, crecimiento y reproducción ${ }^{8}$. Si esa unidad, además, pertenecía a la especie humana, era un ser humano. Entre estas operaciones la nutrición era la condición que permitía al organismo moverse por sí mismo y automantenerse, por lo que se la podía considerar como condición necesaria y suficiente para su existencia y reconocimiento. Todo ente vivo era un organismo?. Haciendo una analogía, pero que permite captar intuitivamente lo esencial de su definición, Aristóteles afirmaba: «Hay que suponer que el animal está constituido como una ciudad bien gobernada. En efecto, en la ciudad, una vez que el ordenamiento queda establecido, no hay en absoluto necesidad de un monarca distinto que deba estar presente en todos los acontecimientos, sino que cada uno por sí mismo hace lo que le corresponde según está establecido, y tal cosa sigue a la otra en virtud de la costumbre; en los animales esto mismo ocurre en virtud de la naturaleza, es decir, que cada una de las partes que los constituyen realiza su trabajo por ser así por naturaleza, de manera que en cada una no hace falta que haya ningún alma, sino que, al estar ésta en el principio del cuerpo, las otras partes viven por estar naturalmente unidas a él, y realizan por naturaleza el trabajo que les es propio» ${ }^{10}$.

En sus rasgos fundamentales estas observaciones no han variado con el tiempo. Hay consenso universal en que la condición de organismo supone un ente vivo que funciona organizada e integradamente, en el que el todo es más que la suma de las partes. Una definición reciente que expresa esta idea es la de W. B. Hurlbut y col.: «La misma palabra "organismo" implica organización -la existencia de un supra-principio que une las partes

8 Cf. A. Vigo, Aristóteles. Una Introducción (Instituto de Estudios de la Sociedad, Santiago 2007), p. 99.

9 Actualmente, con el desarrollo de la biotecnología, surge una dificultad para establecer a la nutrición y a la vida como condiciones suficientes para el reconocimiento de un organismo. Los cultivos celulares y los órganos extraídos para trasplantes son entes vivos que tienen la capacidad de nutrición, pero que evidentemente no son organismos sino sólo partes de éstos artificialmente mantenidas con vida.

10 Aristóteles: Movimiento de los animales, Introducción, traducción y notas de E. JIMÉnez Sánchez-Escariche y A. Alonso Miguel, Ed. Gredos, Madrid, 2000, p. 316 (703a28-703b3). 
y los procesos vitales en un todo coherente y coordinado. En cuanto ser viviente, un organismo es una unidad que se autodesarrolla y automantiene bajo el gobierno de un plan inmanente» ${ }^{11}$. Nicanor Austriaco por su parte, propone otra definición que combina criterios científicos y filosóficos, mostrando como entre ellos no hay contradicción: «Filosóficamente, un organismo se puede definir como una sustancia viva completa, con su propio principio interno de movimiento y cambio, que lo dirige hacia su perfección natural; y científicamente, como una unidad discreta de materia viva que desde sí misma sigue un camino de desarrollo robusto, el que a su vez manifiesta la auto-organización específica de su especie» ${ }^{12}$.

Con todo, este concepto general es acuñado a partir de la observación de organismos multicelulares, en los que la idea de organización y funcionamiento unitario son evidentes. Pero esta condición esencial es difícil de observar en el inicio de su desarrollo cuando, siendo una única célula, es ya sin embargo un organismo. La biología, apoyada ahora con los grandes avances de la biología molecular, ha podido comprobar que el cigoto que resulta de la fecundación tiene un funcionamiento integrado como un todo con un programa robusto de desarrollo. Sin embargo esta constatación empírica se refiere exclusivamente a la del cigoto que resulta de la fecundación, i.e. naturalmente concebido o artificialmente in vitro. Cuándo y cómo sucede esto en una clonación es un tema todavía no dilucidado; y ésa es precisamente la dificultad en la que nos encontramos cuando esta técnica ya tiene la posibilidad de intervenir en esa célula única que podría, o no, ser un organismo humano.

\subsection{Inicio de la vida: fecundación y clonación}

La generación de un nuevo individuo fue un tema que siempre intrigó a filósofos y biólogos. Éste, necesariamente, tenía que ser un evento que ocurría

11 W. B. Hurlbut, R. P. George, M. Grompe, «Seeking Consensus: A Clarification and Defense of Altered Nuclear Transfer», Hastings Cent Rep. 2006 Sept-Oct; 36(5): 42-50.

12 N. Austriaco, Natl Cathol Bioeth Q. 2006 Autumn; 6 (3): 517-37. El autor señala: «Para esta definición estoy en deuda con las iluminadoras concepciones de los siguientes autores: B. Goobwin, "Development as a Robust Natural Process", en Thinking about Biology: An Invitation to Current Theoretical Biology, ed. W. Stein y F. J. VArela (Reading, Mass: Addison-Wesley Publishing Co. 1993), 123-148; y Juan de Dios Vial Correa y Monica Dabike: "The Embryo as an Organism" en The Identity and Status of the Human Embryo, ed. Juan de Dios Vial Correa and Elio S greccia (Vatican City: Libreria Editrice Vaticana, 1999), 317-331». 
en un determinado instante. La dificultad estribaba en precisar el momento preciso en que ocurría. El progreso en las técnicas de investigación permitió grandes descubrimientos en este campo, como el de los gametos y la posibilidad de observación directa del inicio del proceso generativo en la fecundación al poder ver-literalmente- la penetración del espermatozoide en el óvulo (y luego el seguimiento de su crecimiento continuo). Esto se comprobó primero con estudios en animales y luego en humanos, con el advenimiento de la FIV. Con ello se clarificaron muchas de las especulaciones que antes se habían realizado sin sólidos fundamentos empíricos. Ya es revelador que en 1876, Ernst Haeckel, un evolucionista materialista, describía este proceso diciendo: «Si bien debemos considerar al espermatozoide como una célula tan real como el óvulo, y el proceso de la concepción como la fusión de ambos, debemos considerar a la célula resultante como un organismo nuevo e independiente. La mezcla de ambas células es el germen del niño o el nuevo organismo concebido» ${ }^{13}$. Los textos modernos de Embriología, Biología Molecular y Biología del Desarrollo corroboran esta afirmación. Hoy ya no existe discusión sobre que la vida de un nuevo organismo se inicia con la fecundación, con la penetración del espermatozoide en el óvulo ${ }^{14}$. Consecuente con la evidencia científica, el Magisterio ha reconocido estos avances en el conocimiento sobre los inicios de la vida y se ha pronunciado expresamente diciendo: «En realidad, "desde el momento en que el óvulo es fecundado, se inaugura una nueva vida que no es la del padre ni la de la madre, sino la de un nuevo ser humano que se desarrolla por sí mismo. Jamás llegará a ser humano si no lo ha sido desde entonces. A esta evidencia de siempre la genética moderna otorga una preciosa confirmación. Muestra que desde el primer instante se encuentra fijado el programa de lo que será ese viviente: una persona, un individuo con sus características ya bien determinadas. Con la fecundación inicia la aventura de una vida humana, cuyas principales capacidades requieren un tiempo para desarrollarse y poder actuar» ${ }^{15}$ (ver figura 1$)$.

13 E. Haeckel, The Evolution of Man vol. 1 (pp. 53-54), Watts \& CO. 17 Johnson's Court, Fleet Street, London, E.C.1912. Online version Project Gutenberg eBooks 2004-09-0.

14 Por ejemplo, LippincotT, WiLliams \& Wilkins: Langman's Medical Embriology, 2000: «El desarrollo de un individuo comienza con la fecundación, fenómeno por el cual un espermatozoide del varón y el ovocito de la mujer se unen para dar origen a un nuevo organismo, el cigoto». Otro texto importante es S. GilberT, «Fertilization; Beginning a New Organism», en Developmental Biology (cap. 7), ya citado.

15 Evangelium Vitae, 60. 


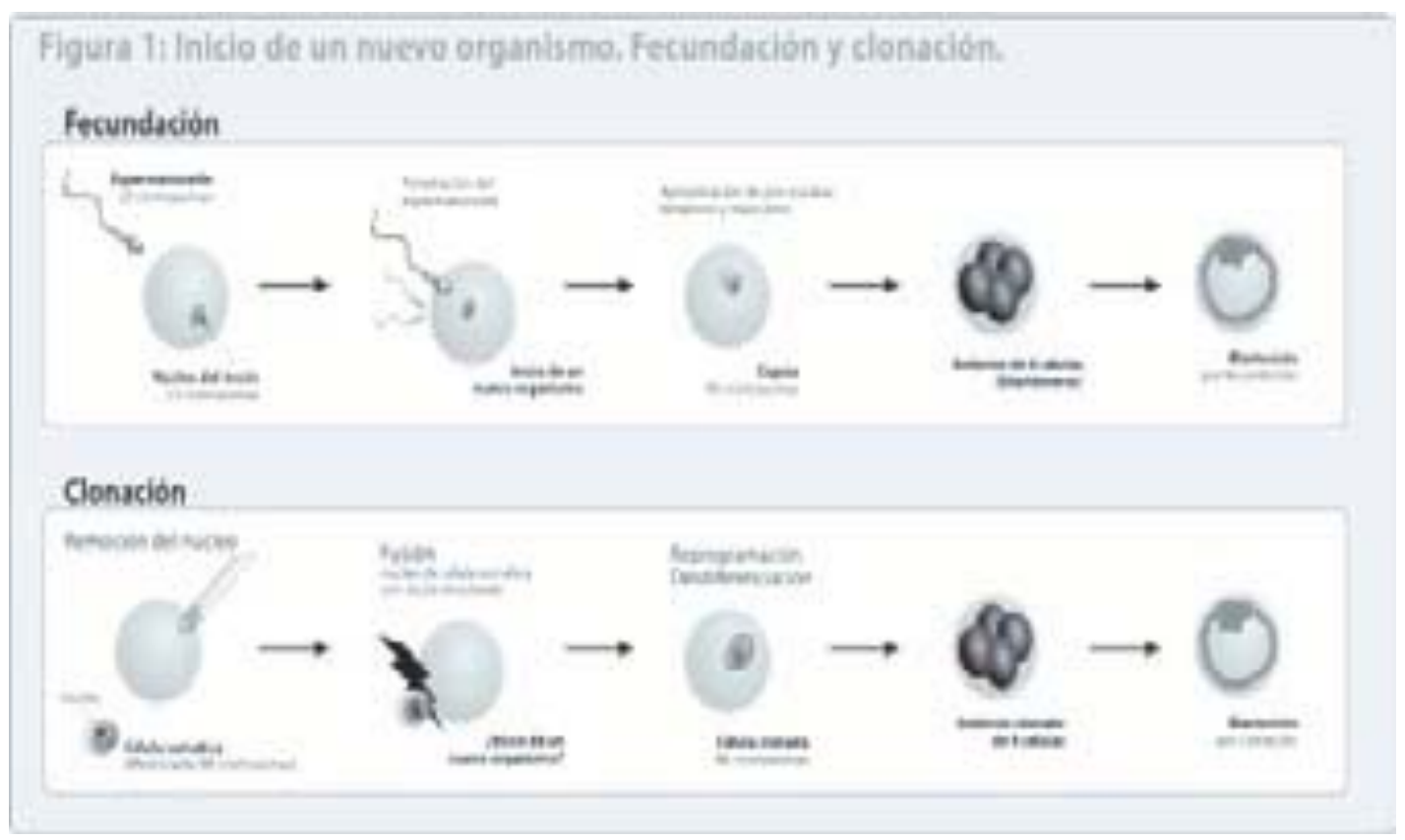

El problema, como ya se ha dicho, surge con la clonación, un avance asombroso de la biotecnología que demostró que la vida de un nuevo organismo no sólo se puede iniciar a través de la fecundación, sino que también se podía producir por medio de otros procedimientos artificiales. El tema, aunque ya se conocía en el ámbito de la ciencia con respecto a otras especies ${ }^{16}$, saltó a la luz pública en 1997 con la creación, vía SCNT, de la oveja Dolly —un mamífero, que se reproduce en forma sexuada de un modo semejante a los seres humanos ${ }^{17}$. La clonación vía SCNT (ver

16 Por ejemplo, R. Briggs y T. J. KING, «Transplantation of Living Nuclei from Blastula Cells into Enucleated Frog's Eggs», Proc. Nat. Acad. Sci. 38, pp. 455-463, (1952); o J. B. Gurdon, R. A. Laskey y O. R. Reeves, «The Developmental Capacity of Nuclei Transplanted from Keratinized Skin Cells of Adult Frogs», J. Embryol. Exp. Morph. 34, pp. 93-112 (1975).

17 Cf. I. Wilmut, A.E. Schnieke, J. McWhir, A.J. Kind, K. H. Campbell, «Viable Offspring Derived from Fetal and Adult Mammalian Cells», Nature, Feb 27, 1997; 385(6619):810-3. En la actualidad, el procedimiento se ha reproducido al menos en otras 15 especies de mamíferos: conejos, ratas, vacas, caballos, etc. K. H. CAMPBELL, R. Alberio, I. Choi, P. Fisher, D.R. Kelly, J. H. Lee, W. Maalouf, «Cloning: Eight Years after Dolly», Reprod Domest Anim. 40, n. 4 (2005), pp. 256-268. Recientemente también se ha publicado por primera vez la clonación de seres humanos (aunque hasta la fecha no hay comunicaciones de que de estos embriones se haya logrado extraer y cultivar CME). Cf. French, A. J., Adams, C. A., Anderson, L. S., Kitchen, J. R., Hughes, M. R., Wood, S. H.: «Development of Human Cloned Blastocysts following Somatic Cell Nuclear Transfer with Adult Fibroblasts», Stem Cells 26, n. 2 (2008): pp. 485-493. 
figura 1) es un procedimiento artificial que permite producir organismos sin la intervención de gametos. En éste se transfiere el núcleo de una célula diferenciada a un óvulo de la misma especie al cual se le ha extraído el núcleo. En ese momento la nueva célula comienza un proceso de desdiferenciación del núcleo transferido hasta, idealmente, llegar a un estado denominado de totipotencialidad (equivalente al del cigoto en la fecundación) desde el cual se inicia una embriogénesis similar a la de todos los ejemplares de esa especie. El animal resultante tiene un genoma nuclear idéntico al del animal del cual proviene el núcleo de la célula transferida (ver figura 1).

En términos netamente científicos, esta técnica no ha resultado muy eficiente. Con Dolly, de hecho, se requirieron 277 transferencias de las cuales se desarrollaron 29 embriones aptos para ser trasplantados y sólo uno llegó a ser viable: Dolly. Con todo, el patrón de desarrollo de la biotecnología permite prever que, en caso de que se continuara por esta misma línea investigativa, el procedimiento se podría ir perfeccionando y su eficiencia también aumentaría. Sin embargo, ése no es el tema que a la bioética le preocupa. Al margen de la actual ineficiencia técnica de la SCNT, el mero hecho de que en un caso se haya desarrollado una oveja (indudablemente un organismo) permite saber que (a) se pueden generar organismos de modo distinto a la fecundación, pero (b) no se puede (aún) precisar en qué momento del proceso de clonación se inicia la vida de un nuevo $\operatorname{ser}^{18}$. Y si todos los casos de clonaciones frustradas fueran exactamente iguales al que produjo a Dolly, se estaría siempre ante la posibilidad de que esas células fueran también organismos.

Naturalmente, en los primeros intentos de este procedimiento no se sabía si la célula resultante de la fusión del núcleo con el óvulo enucleado era o no un organismo. Fue necesario observar su desarrollo. Pero cuando éste ya se ha visto, sí se puede hacer la inferencia y establecer, a posteriori, que en algún momento del proceso que comienza con la SCNT la célula intervenida se constituye en un nuevo organismo. No obstante, como la información biológica no ha determinado cuándo ocurre ese evento (a diferencia de lo que sucede con la fecundación),

18 Decir «se inicia» encierra, sin embargo, precisamente el tema que aquí está en discusión: ¿cuál es propiamente «su inicio»? ¿Hay organismo desde el momento mismo de la fusión o bien desde algún momento posterior a ésta? Pero lo que no está en discusión es que ese «inicio» corresponde al de un organismo unicelular, y el problema de la bioética está en saber cómo reconocerlo. 
toda eventual manipulación de células humanas creadas vía SCNT es éticamente reprobable, por cuanto el «principio de cautela» obliga a no aceptar el riesgo de estar manipulando e instrumentalizando organismos humanos.

\subsection{Células Madres Embrionarias (CME)}

La urgencia para la bioética de encontrar índices o criterios que permitan reconocer a un organismo humano unicelular artificialmente producido se acentuó con el descubrimiento de las CME y sus revolucionarias posibilidades terapéuticas ${ }^{19}$. La promesa de la medicina regenerativa, que permitiría dar un gran salto cualitativo a la medicina tradicional, es que células dañadas de diversos tejidos del organismo puedan ser reemplazadas por células sanas provenientes de las CME, permitiendo el tratamiento y eventual curación de diversas enfermedades que hasta ahora no tienen tratamiento efectivo, como el caso del Parkinson, el Alzheimer, la leucemia, la esclerosis lateral amiotrófica, etc. La investigación en las CME, por tanto, ha generado grandes expectativas en todo el mundo. Sin embargo dicha investigación también implicaría (no necesariamente, aunque hasta el momento así ha sucedido) la intervención tecnológica en una vida humana naciente ${ }^{20}$. En la actualidad, las CME se obtienen de los embriones sobrantes de la FIV y se está trabajando para también poder hacerlo de embriones producidos vía SCNT. En ambos casos los embriones son destruidos haciendo esta técnica inaceptable para quienes reconozcan en el embrión a una persona.

19 Ésta ha sido una de las grandes hazañas de la ciencia y tecnología del último tiempo. En 1981, Evans (Evans, M. J. y Kaufman, M. H.: «Establishment in Culture of Pluripotential Cells from Mouse Embryos», Nature 292 (1981): pp. 154-156) y Martin (Martin, G. R.: «Isolation of a Pluripotent Cell Line from Early Mouse Embryos Cultured in Medium Conditioned by Teratocarcinoma Stem Cells», PNAS 78 n. 12 (1981): pp. 7634-7638), en dos estudios independientes, lograron por primera vez extraer células del macizo celular interno de un embrión de ratón y cultivarlas in vitro. En 1998, Thompson y col. realizaron lo mismo a partir de un blastocisto humano (Thomson, J. A., Itskovitz-Eldor, J., Shapiro, S. S., Waknitz, M. A., Swiergiel, J. J., Marshall, V. S., y Jones, J. M.: «Embryonic Stem Cell Lines Derived from Human Blastocysts», Science 282 (5391), (1998): pp. 1145-1147). Martin Evans obtuvo el premio Nobel de Medicina en el año 2007.

20 Como veremos más adelante, ya existen alternativas para producir CME sin necesidad de destruir embriones humanos. 
Para comprender la importancia de las CME para la ciencia y la bioética hay que saber qué son y por qué poseen estas características tan importantes. En la etapa del desarrollo del embrión humano, alrededor del cuarto o quinto día post fecundación, se constituye el blastocisto, el cual se caracteriza por tener una estructura con una cavidad en la cual se encuentra un grupo de células (alrededor de 70 a 100) que forman lo que se denomina el macizo celular interno (MCI). Éstas son llamadas «células pluripotenciales» debido a que tienen la capacidad de formar todos los tejidos del organismo en desarrollo (ver nota 5). La capa externa del blastocisto, por su parte, está constituida por las células del trofoblasto, que son las que posteriormente constituirán la placenta. Actualmente, cuando se habla de CME, se trata de las células extraídas del MCI (o producidas artificialmente de algún otro modo). Éstas tienen dos características fundamentales. Una es su capacidad de multiplicarse indefinidamente sin diferenciarse, manteniendo su condición de ser pluripotenciales. La segunda es que por mantener la pluripotencialidad pueden diferenciarse y formar -cuando son cultivadas y tratadas de manera especial- los diferentes tejidos del organismo ${ }^{21}$. De ahí que estas células podrían, de acuerdo con las necesidades propias de cada enfermedad, generar tejidos que reemplacen las células dañadas y remedien aquellas patologías que se caracterizan por la pérdida irrecuperable de células sanas en los diversos órganos del cuerpo.

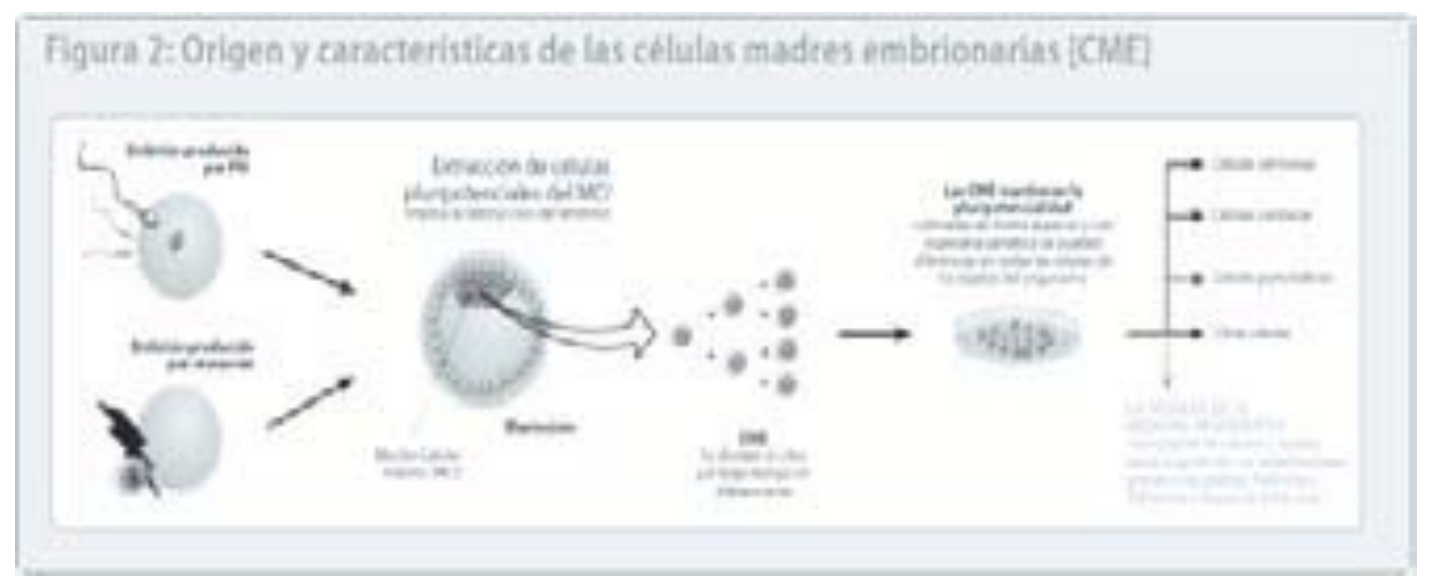

Ahora bien, las CME son células pluri-potenciales por cuanto tienen la capacidad de formar cualquier tejido del organismo. En vistas a nuestra discusión, sin embargo, es esencial distinguirlas de las llamadas células

21 Cf. «Embryonic Stem Cells», cap. 1, por J. Yu y J.A. Thomson en: http://stemcells. nih.gov/staticresources/info/scireport/PDFs/Regenerative_Medicine_2006.pdf 
toti-potenciales, que son las que tienen la capacidad de formar un nuevo organismo (y no sólo «algún tejido» de éste), i.e. en la fecundación natural: el cigoto. En consecuencia, una célula totipotente se identifica con el inicio de un nuevo organismo; una célula es totipotente porque es ya un organismo entero (toti - todo). El cigoto, a diferencia de cualquier otra célula, tiene la capacidad o potencia intrínseca de desarrollar todo el organismo en la medida en que se encuentre en el medio adecuado. Las células pluripotenciales, como son las CME, no tienen esta capacidad: no son cigotos, no son personas; y su utilización terapéutica no presenta, en sí misma, ninguna objeción moral.

No obstante, hay que advertir que el término «célula totipotencial» se usa con frecuencia para denominar a todas las células que forman el embrión en sus primeros días (los blastómeros). Esta ambigüedad puede inducir a un grave error, pues significaría que en estas primeras etapas de desarrollo el embrión estaría formado por varios organismos ${ }^{22}$. La razón de esta imprecisión deriva de que cuando un blastómero es separado del embrión tiene la capacidad de reprogramarse para desarrollar un nuevo organismo, como ocurre en el caso la gemelación. Pero es sólo en este momento cuando esa célula adquiere, en estricto rigor, el carácter totipotente ${ }^{23}$.

22 Cf. B. Smith, B. Brogand, «Sixteen days», J Med Philos. 2003 28(1): pp. 45-78. Este argumento es rebatido por G. Damschen, A. Gómez-Lobo y D. Schönecker en «Sixteen Days? A Reply to B. Smith and B. Brogaard on the Beginning of Human Individuals», J Med Philos. 2006 31(2): pp. 165-175. Una objeción concreta es la que realiza A. Gómez-Lobo, en «Aristóteles y una disputa bioética», Estudios Públicos 102, 2006, pp. 28-42; donde básicamente arguye que la identidad actual de una célula no implica su identidad previa. Vale decir, que una célula sea ahora totipotente no significa que antes de separarse del blastocisto también lo era (como un cadáver o cuerpo inerte no implica que éste antes no estuviera vivo).

Los mecanismos moleculares que controlan la totipotencialidad no son aún bien comprendidos por la ciencia. Cf. R. Ciosk, M. DePalma, J. R. Priess, «Translational Regulators Maintain Totipotency in the Caenorhabditis Elegans Germline», Science 311(5762), (2006): pp. 851-853; y también J. M. Pagano, B. M. Farley, K. I. Essien, S. P. Ryder, «RNA Recognition by the Embryonic Cell Fate Determinant and Germline Totipotency Factor MEX-3», Proc Natl Acad Sci U. S. A., Nov. 13, 2009. Para el caso de la gemelación, en consecuencia, la Biología todavía no puede dar una respuesta precisa, pero sí se sabe que en su primera etapa de desarrollo los blastómeros, al desprenderse del embrión, tienen la capacidad de reprogramarse para constituir un nuevo organismo. 
Ahora bien, en el caso de la fecundación es claro que en la fusión del óvulo con el espermio se forma el cigoto, una célula totipotente. Pero en el caso de la SCNT no está precisado el momento en que la célula compuesta por un núcleo diferenciado transferido al óvulo enucleado llega al estado de totipotencialidad, es decir, a convertirse en un nuevo organismo. Y como para obtener CME (o células pluripotenciales) se ha venido prioritariamente realizando vía destrucción de embriones (FIV o eventual SCNT), el gran desafío para quienes defienden la dignidad humana desde su inicio es encontrar otros medios para obtener esas mismas células con sus mismos beneficios terapéuticos ${ }^{24}$, pero sin destruir embriones. Una de éstas es la que expondremos a continuación, cuyo objetivo central es, a través de una modificación de la SCNT, obtener CME que no pasen nunca por el estado de totipotencialidad; vale decir, que no sean en ningún momento un cigoto humano.

\subsection{La técnica «ANT-OAR»}

Este procedimiento no es más que uno de los que se han propuesto para obtener células pluripotenciales sin el riesgo de violar la dignidad de una persona, pero es el que hemos escogido como instrumento para aclarar y situar el problema, extrayendo también algunas conclusiones del gran debate que en su momento produjo entre los expertos pro-vida. En concreto, esta técnica consiste en una modificación de la SCNT; primero a través de la llamada Transferencia Nuclear Alterada o ANT («Altered Nuclear Transfer»), y luego agregando también la denominada Reprogramación del Óvulo Enucleado u OAR («Oocyte Assisted Reprogramming»).

La ANT, en primer lugar, consiste en alterar el núcleo que será transferido al óvulo enucleado, silenciando uno o más de los genes considerados indispensables para el funcionamiento integrado y unitario de un organismo; o, lo que sería lo mismo, aquellos genes responsables de la totipotencialidad. De este modo el ente producido no llegaría nunca a ser un embrión, sino un mero artefacto biológico del cual se podrían obtener células pluripotenciales idénticas o muy semejantes a las $\mathrm{CME}^{25}$ (ver Figura 3).

24 P. Ventura-Juncá, M. Santos, J. Larrain, «Proposals for Embryonic Stem Cell Production without Destroying Human Embryos: Scientific and Bioethical Challenges», Acta Bioetbica, en prensa.

25 Cf. W. B. HuRLBut, «Altered Nuclear Transfer as a Morally Acceptable Means for the Procurement of Human Embryonic Stem Cells», paper presentado al Consejo Presidencial de Bioética (EE. UU.) el día 3 de diciembre del 2004. 


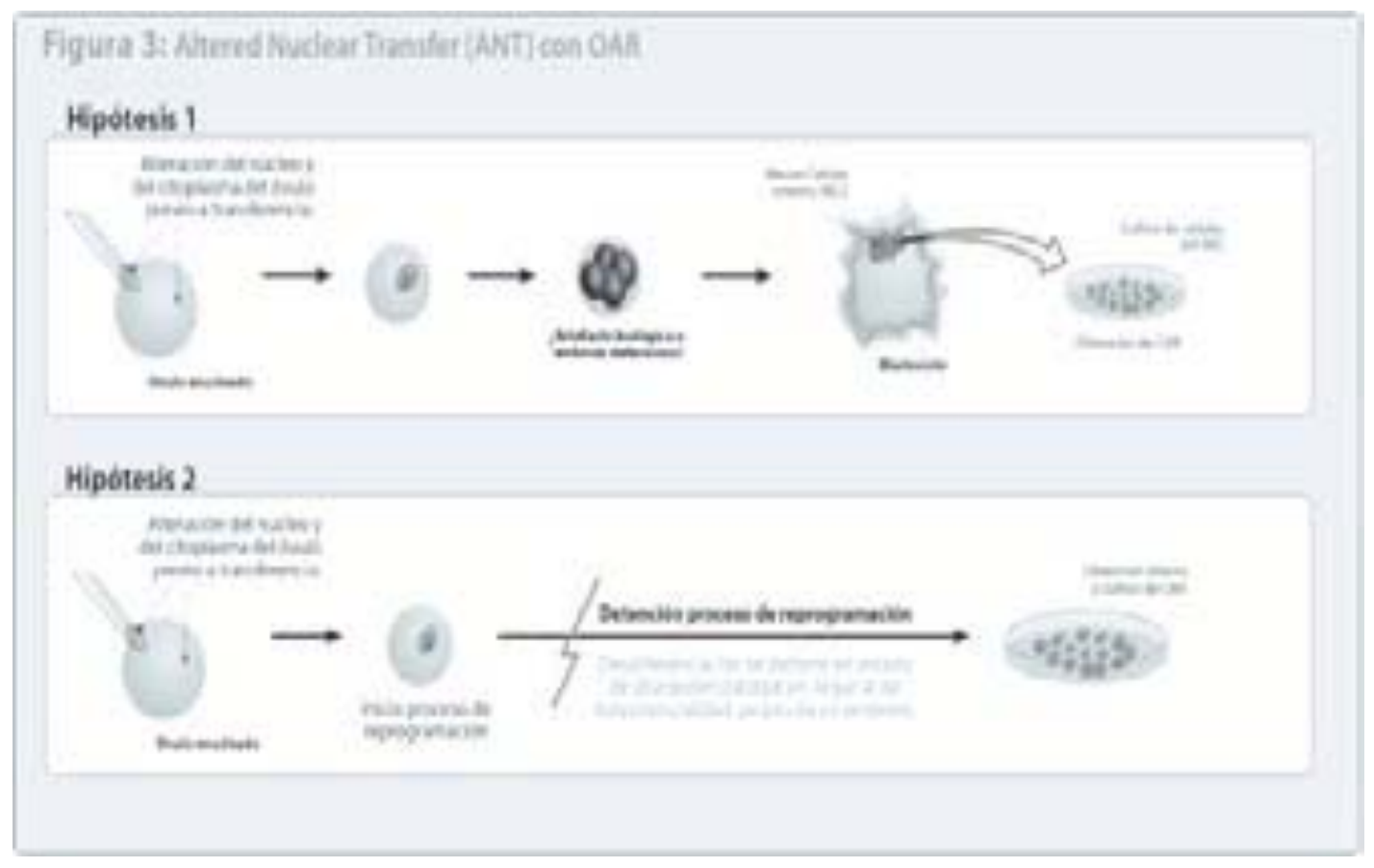

La activación o silenciamiento de los genes es lo que se denomina una modificación epigenética o una epimutación. Éste es el modo a través del cual la ANT busca evitar la producción de un embrión humano. Es decir, los genes del núcleo transferido no se modifican en su estructura o la secuencia de su DNA (mutación), que es lo que comúnmente se denomina «genoma» y que se encuentra en el núcleo de la célula ${ }^{26}$. Lo que sí se altera, en cambio, es la expresión de alguno(s) de estos genes: se activa o se silencia su función, que es precisamente la que representa o da lugar al modo según el que se generan los distintos tipos de células ${ }^{27}$.

26 El término «genoma» posee una cierta ambigüedad, pero aquí lo utilizaremos aludiendo al DNA organizado tal como se encuentra en la gran mayoría de las células. En la especie humana el genoma nuclear está distribuido en 46 cromosomas (23 de cada progenitor) y posee alrededor de 25.000 genes. El «genoma mitocondrial», que se encuentra en las mitocondrias (fábricas energéticas) dentro del citoplasma, y por tanto fuera del núcleo, es mucho más pequeño (37 genes) y se transmite sólo por la madre.

27 Todas las células del cuerpo tienen el mismo genoma o secuencia de DNA. No obstante, ellas se distinguen -son células cardíacas, neuronas, epidérmicas, etc.- de acuerdo con cuál de los genes que contiene su DNA se está expresando. Una epimutación, que es el instrumento del que pretende servirse la ANT, consiste precisamente en alterar la expresión de los genes necesarios para que la célula sea totipotencial o, como se ha dicho, un embrión humano. La epimutación no es lo mismo que una mutación genética. De hecho, en el proceso del desarrollo embrionario se va produciendo la diferenciación de sus células pluripotenciales en las más diversas células de los tejidos del organismo; pero todas mantienen el mismo genoma. No hay mu- 
Existe un único estudio en que se ensayó la técnica de la ANT, en ratones, silenciando el gen $\mathrm{Cdx} 2$ del núcleo a transferir. El resultado fue un ente vivo que se desarrolló en forma desorganizada hasta formar un blastocisto muy anormal ${ }^{28}$. De su MCI se extrajeron células madres que pasaron los test científicos de pluripotencialidad ${ }^{29}$. Se pensó entonces que se había encontrado un modo de producir células madres sin necesidad de destruir embriones. No obstante, al poco tiempo comenzó la discusión sobre si el producto de esta ANT era efectivamente un mero artefacto biológico, o si no era más bien un embrión defectuoso. Ambas alternativas eran posibles: el silenciamiento del Cdx2 podía, perfectamente, no haber impedido la creación del embrión sino sólo el desarrollo normal de éste, deteniendo su crecimiento en una etapa muy temprana del mismo. La discusión, a nuestro juicio, quedó definitivamente zanjada cuando los propios autores del experimento señalaron que el desarrollo de las primeras divisiones de este «ente biológico» era semejante a las de un embrión normal mientras no requiriera la expresión del gen Cdx2. Por lo tanto, con su silenciamiento, no se habría cumplido el objetivo esperado, sino que simplemente se habría creado un embrión al que artificialmente se le habría impedido superar cierta etapa de su desarrollo.

Ahora bien, la OAR es también una modificación de la SCNT que puede combinarse con la ANT. Ésta consiste en que, además de modificar epigenéticamente el núcleo a transferir, se modifica también el óvulo enucleado receptor, activando la expresión del gen NANOG (que se encuentra activo en las células pluripotenciales pero no en el cigoto). Entonces, con la fusión del núcleo de la célula somática y el óvulo enucleado se

taciones, pero sí cambian su estado epigenético. Esto quiere decir que el proceso de diferenciación celular es epigenético.

Cf. A. Meissner, R. Jaenisch, «Generation of Nuclear Transfer-derived Pluripotent ES Cells from Cloned Cdx2-deficient Blastocysts», Nature 439 (7073) (2006): pp. 212-215. El gen Cdx2 es principalmente responsable del desarrollo del trofoblasto, indispensable para la implantación del embrión.

29 El principal «test de pluripotencialidad» es la inyección de estas células obtenidas por ANT en un blastocisto normal -en el caso de este experimento, el de un ratón- que luego se desarrolla como un ratón quimera. Esto es, aquel en el que las células de los diferentes tejidos provienen tanto de sus células pluripotenciales como de las CME inyectadas. Normalmente se trata de que sean cepas de diverso color para que resulte fácil comprobar el origen diverso de sus células. El test es científico, empírico, lo que implica una verificación de hecho: su resultado sólo se puede conocer a posteriori, tras el desarrollo del ente producido. 
iniciaría el proceso de des-diferenciación hacia la totipotencialidad, propia de toda SCNT, pero gracias a las alteraciones realizadas no se llegaría nunca a la producción de un embrión. Dicho de otro modo, con esta técnica se «detendría» el proceso de des-diferenciación nuclear antes de llegar al estado de totipotencialidad asociado al embrión humano, produciendo directamente células pluripotenciales (ver Figura 3).

Este procedimiento creó grandes expectativas entre científicos, filósofos, teólogos y otros expertos pro-vida; hasta el punto de que suscribieron, en junio del 2005, una Declaración Conjunta (Joint Statement) apoyando, en principio, la producción de CME a través la $\mathrm{OAR}^{30}$.

Con todo, para explicar los resultados de esta técnica es todavía posible postular dos hipótesis. La primera puede ser más compleja, ya que en algún sentido se la podría asemejar con la ANT y el silenciamiento del gen Cdx2. Ésta, planteada por especialistas como Christian Brugger y Nicanor Austriaco, afirma que con la OAR no se obtendrían de modo directo o inmediato células pluripotenciales; sino que se produciría una suerte de artefacto biológico que al no ser totipotencial (por la expresión del gen NANOG) no se podría identificar con un embrión, pero sí poseería la expresión génica de la pluripotencialidad y la capacidad de dividirse y llegar a producir células pluripotenciales (es decir, a través de esta epimutación

30 Cf. H. Arkes et al., «Production of Pluripotent Stem Cells by Oocyte-assisted Reprogramming: Joint Statement with Signatories», Natl Cathol Bioeth Q. 5 n. 3 (2005): pp. 579-583. El primer párrafo de esta Declaración Conjunta señala: «Tal como se describe en el White Paper del Consejo Presidencial de Bioética, la Transferencia Nuclear Alterada (ANT) es una propuesta conceptual amplia para producir células germinales pluripotentes sin crear ni destruir embriones. En la descripción que sigue, reseñamos un programa de investigación para una forma de ANT que debería permitirnos producir células pluripotentes sin crear ni destruir embriones humanos, $y$ sin producir ninguna entidad que pase por alguna etapa o imite de algún modo el desarrollo embrionario. El método de alteración que aquí se propone (Reprogramación Asistida del Ovocito) produciría de modo inmediato una célula con las características y tipo de organización [de una célula pluripotencial, pero que] desde su inicio sería clara e inequívocamente distinta e incompatible con los de un embrión. Sin la posibilidad de ser ni de transformarse en un embrión, la célula pluripotente producida podría cultivarse para establecer una línea de células pluripotenciales. Fundamentalmente, esta célula no sería totipotencial, como los cigotos sí lo son». Naturalmente los suscriptores pusieron todas las condiciones correspondientes al «principio de cautela» antes de que esta técnica siquiera se pruebe en células humanas, es decir, antes de tener la certeza absoluta de que la célula producida llegue, alguna vez, al estado de totipotencialidad. 
se podría hacer una suerte de by-pass del estado embrionario y llegar a un ente semejante al blastocisto, con una especie de «macizo celular interno» del cual se podrían extraer CME). La segunda hipótesis, en cambio, dice que las alteraciones epigenéticas efectuadas en el núcleo y el óvulo detendrían realmente el proceso de des-diferenciación antes de llegar a la totipotencialidad; y sólo se alcanzaría el estado epigenético característico de pluripotencialidad. Con esto, se crearía directa e inmediatamente una célula pluripotencial que nunca pasaría por la totipotencialidad; vale decir, nunca existiría un embrión y no podría, obviamente, ser destruido (ver las dos hipótesis graficadas en la Figura 3).

Hasta la fecha no existen resultados empíricos publicados que validen la factibilidad de esta técnica, por lo que la discusión sólo se limita a un plano teórico. Incluso más: es probable que el debate específico respecto de la ANT-OAR como medio para obtener células madres sin destruir embriones no continúe, pues en el año 2006 el científico Shinya Yamanaka descubrió, como ya ha sido corroborado por varios otros investigadores, la posibilidad de obtener células pluripotenciales mediante la alteración epigenética de células somáticas por medio de la introducción de genes o factores capaces de inducir la reprogramación de la célula a su estado pluripotencial ${ }^{31}$. La relevancia de este descubrimiento fue reconocida por la Revista Science en el 2008, calificándolo como el mayor avance en las ciencias empíricas del año. Los científicos consideran que si este procedimiento se prueba efectivo en la producción de lo que se ha denominado células madres o células pluripotenciales inducidas, éste sería más fácil, eficiente y económico que hacerlo vía SCNT; y también tendría, respecto de las CME extraídas de embriones sobrantes de la FIV, la ventaja de no generar rechazo en ningún sector social, ya que no implica el uso de óvulos ni embriones humanos, y se podrían utilizar células somáticas del mismo paciente al cual se va a tratar. Esta técnica, en definitiva, tal como fue planteada en sus inicios, no presentaría entonces ningún riesgo para la dignidad de una vida humana. Sin embargo, hay que señalar que científicos chinos ya dieron un

31 K. Takahashi y S. Yamanaka, «Induction of Pluripotent Stem Cells from Mouse Embryonic and Adult Fibroblast Cultures by Defined Factors», Cell 126 (2006), pp. 663-676. Cf. también M. Wernig, A. Meissner, R. Foreman et al., «In Vitro Reprogramming of Fibroblasts into a Pluripotent ES-cell-like State», Nature 448(7151) (2007): pp. 318-324; y K. Takahashi, K. Tanabe, M. Ohnuki, M. Narita, T. IchiSAKa, K. Tomoda, S. Yamanaka, «Induction of Pluripotent Stem Cells from Adult Human Fibroblasts by Defined Factors», Cell 131 (2007): pp. 861-872. 
paso más allá, y modificando la técnica original de Yamanaka -así como su finalidad- ya lograron a producir una célula totipotente, es decir, un organismo capaz de desarrollarse hasta adulto en forma semejante a la clonación. Ello pone a la bioética en un problema análogo al que aquí discutimos. Aunque en este caso no ni siquiera interviene un óvulo; sino que de una célula de la cola de un ratón, modificando las técnicas de reprogramación iniciadas por Yamanaka, han producido otro ratón: un clon, un nuevo organismo. Indudablemente que esto abre una nueva dimensión a la discusión bioética. ${ }^{32} 33$

En consecuencia, aunque se encuentre una forma ética de producir células pluripotenciales, el rápido avance de la biotecnología demuestra que si no es para la producción de las CME, será otro el problema en el que se pondrá nuevamente en jaque la condición de organismo del producto de otras técnicas susceptibles de ser usadas en humanos, tales como la recién mencionada, la hibridación (mezcla de células y/o gametos de diversas especies $^{34}$ ) o la partenogénesis (producción de un organismo a partir de un único gameto, el óvulo ${ }^{35}$ ). Por ello es que la discusión acerca de la determinación de criterios o índices para identificar con seguridad a un nuevo organismo humano producido artificialmente, en su etapa unicelular, se mantiene vigente; máxime dado el valor absoluto, la sacralidad de la vida humana que defiende la Iglesia Católica ${ }^{36}$. Y el debate que a continuación expondremos persigue precisamente ese fin, que en última instancia significa dilucidar cuándo éstos o futuros avances de la biotecnología son un verdadero progreso, y no son más bien un retroceso, para la humanidad.

32 M.J. Boland, J.L. Hazen, K.L. Nazor, A.R. Rodriguez, W. Gifford, G. Martin, S. Kupriyanov, K.K. Baldwin, «Adult Mice Generated from Induced Pluripotent Stem Cells», Nature. Sep 3 (2009); 461(7260):91-94.

33 Z. Kou, L. Kang, Y. Yuan, Y. Tao, Y. Zhang, T. Wu, J. He, J. Wang, Z. Liu, S. GaO, «Mice Cloned from Induced Pluripotent Stem Cells (iPSC)», Biol Reprod. (2010), Apr 28.

34 Cf. Y. Chung, C.E. Bishop, N.R. TrefF, y col., «Reprogramming of Human Somatic Cells Using Human and Animal Oocytes», Cloning Stem Cells 11 n. 2 (2009): pp. 213223. Ya se han realizado los primeros estudios de transferencia nuclear de células adultas humanas a óvulos enucleados animales.

35 Con esta última, de hecho, ya se ha logrado producir CME en humanos. Cf. T. A. Brevini, F. Gandolfi, «Parthenotes as a Source of Embryonic Stem Cells», Cell Prolif. 41 Suppl. 1 (2008): pp. 20-30.

36 Cf. F. Chomali, Bioética..., pp. 227-235. 


\section{El debate}

La discusión que expondremos se realizó principalmente durante el año 2005, en la revista Communio, entre algunos expertos que defendían la ANT-OAR como una técnica moralmente lícita para la obtención de CME -tales como Nicanor Austriaco, Christian Brugger y W. B. Hurlbut (autor de la propuesta original) - y otros -como Adrian J. Walker, David L. Schindler y José Granados- que se oponían al procedimiento afirmando que su producto era un embrión humano desde el principio, i.e. desde la fusión del núcleo de la célula somática con el ovocito enucleado. El problema, entonces, no estaba en el concepto general de organismo ni su reconocimiento en caso de la fecundación, sino en la búsqueda de criterios y signos ciertos para poder reconocer al organismo humano unicelular en el caso de nuevos tipos de producción artificial, y poder con ello defender su dignidad.

A lo largo del debate se fueron dando diversos criterios de reconocimiento, que fueron cuestionados y forzados a encontrar más y mejores argumentos para su defensa. De este modo se fue generando un fructífero «diálogo cooperativo» donde las propuestas, contrastes y refutaciones obligaron a precisar y justificar, tanto desde el ámbito empírico como el filosófico, los índices propuestos. El debate obviamente ha ido creciendo en complejidad, pero también ha demostrado que sólo en este encuentro y desencuentro de opiniones y en el espacio de la cooperación interdisciplinar, va a ser posible alcanzar alguna posición compartida que, al menos con el actual estado del conocimiento científico, otorgue un marco orientativo para las posturas que inevitablemente debe tomar la bioética respecto de los rápidos avances de la biotecnología. En la discusión que expondremos los cinco criterios más relevantes para reconocer a un organismo humano unicelular artificialmente producido fueron:

a) La fusión del núcleo con el óvulo enucleado en la SCNT, que equivaldría a la fusión del espermatozoide con el óvulo en la fecundación

b) La posesión de un genoma humano razonablemente completo

c) La procedencia del ente vivo generado

d) El estado epigenético del cigoto

e) La capacidad de expresarse como organismo y de desarrollo autodirigido 


\subsection{Primeros argumentos}

El argumento de base de los detractores de la técnica ANT-OAR es que la fusión del núcleo de la célula somática con el óvulo enucleado es, tal como en cualquier SCNT, un evento equivalente a la fecundación (a la penetración del óvulo por el espermatozoide). Junto a ello, agregan que en la fusión que ocurre en la SCNT o sus modificaciones (ANT y OAR) se introduce un genoma razonablemente completo (criterio (b)), lo que lo asemejaría aún más a la fecundación natural en la que por la unión de los gametos masculino y femenino se forma un nuevo genoma; y que también habría una equivalencia con la fecundación por cuanto este genoma se constituiría por la unión de los 23 cromosomas masculinos y femeninos, aunque en el caso de la SCNT esto suceda en forma remota (criterio (c)). Concluyen, con esto, que tanto en la fecundación como en la clonación se dan los tres primeros criterios de reconocimiento del organismo humano unicelular y en consecuencia la ANT-OAR sí generaría de modo inmediato un nuevo organismo, lo que haría ilícito utilizarlo para la extracción de CME. Todo el proceso que esta célula inicia tras la fusión no serían más que etapas del desarrollo de aquello que surgió «absolutamente» en el momento de la transferencia nuclear.

Los textos de Walker son muy explícitos en este punto: «Decir que X es un organismo humano es tan simple como decir que $\mathrm{X}$ llegó a ser por la constitución de un nuevo genoma humano razonablemente normal, formado por la unión del número correcto de cromosomas femeninos y masculinos ${ }^{37}$. Schindler refuerza este argumento citando la Evangelium Vitae: «La [EV], en el párrafo 60, señala que la vida comienza «desde el momento en que el óvulo es fecundado», por tanto, desde el momento en que el óvulo y el espermio -lo que en una concepción imitada equivale a la transferencia nuclear de una célula somática a un ovocito enucleado- se fusionan ${ }^{38}$. Schindler también dice que entre la ANT y la OAR no hay

37 A. WALKer, «Altered Nuclear Transfer: A Philosophical Critique», Communio: International Catholic Review 31 (2005), pp. 649-684: p. 656. También dice: «Podemos formular el siguiente criterio para establecer el status de organismo: Todo lo que $\mathrm{X}$ requiere para ser considerado un organismo humano en su sentido esencial, es haber llegado a ser a través de la fecundación. Nótese que la fecundación es, o coincide con, el evento en el que un nuevo genoma humano es constituido por el número correcto de cromosomas derivados del hombre y la mujer» (p. 664 n. 34).

38 D. SCHIndLeR, «A Response to the Joint Statement, «Production of Pluripotent Stem Cells by Oocyte Assisted Reprogramming'», Communio: International Catholic Review 32 
mayor diferencia, puesto que lo esencial para la formación de un nuevo organismo es la fusión del núcleo y el óvulo enucleado -como se da en cualquier SCNT- independientemente de que la célula resultante pase o no inmediatamente al estado pluripotencial de las CME. Por consiguiente, lo que haría la ANT-OAR no sería más que una modificación del programa de desarrollo de un organismo que ya existe, aunque esa existencia sea muy efímera en el tiempo ${ }^{39}$.

En defensa de la técnica ANT-OAR sus proponentes objetan estos argumentos, problematizando ya los criterios dados para el reconocimiento de un organismo que no sea fruto de una fecundación. En relación al criterio (a), dicen que el proceso de la SCNT es muy diferente al de la fecundación. Con la fusión sólo comienza un proceso de reprogramación, de des-diferenciación epigenética del núcleo de la célula somática diferenciada, que es el proceso inverso al que ocurre en el desarrollo del embrión: la progresiva diferenciación de las células para integrar los diversos tejidos del organismo. En el primer caso hay una trayectoria de des-diferenciación epigenética de un núcleo diferenciado por acción del citoplasma del óvulo. Cuando la reprogramación alcanza el estado de totipotencialidad, que es el característico del cigoto, recién entonces se está en presencia de un nuevo organismo. Aducen así el cuarto criterio mencionado referente a la importancia del estado epigenético para la identificación del organismo unicelular. La totipotencialidad de la célula, que se asocia a un determinado estado epigenético, sería el índice de la existencia de un nuevo organismo, capaz de desarrollarse como un ejemplar normal de su especie.

Luego refutan también el segundo criterio que utilizan los detractores de la ANT-OAR: el que se refiere a la posesión de un genoma humano razonablemente completo. De hecho, lo que diferencia a las diversas células del organismo -como ya dijimos- no es que tengan un genoma distinto sino los genes que en ella se expresan, i.e. su estado epigenético. Los textos de Austriaco son muy claros al respecto, diciendo que si bien la posesión de un genoma razonablemente completo es condición necesaria

(2005), pp. 369-380: p. 373. Habría que precisar, sin embargo, que la encíclica de Juan Pablo II sólo se refiere al caso de la fecundación y no menciona el de la clonación.

39 Según Schindler lo que los proponentes de la OAR llaman «reprogramación epigenética» del núcleo de una célula somática en el ovocito enucleado debería llamarse, para una mayor precisión, una «modificación planificada del desarrollo del conceptus humano a través de métodos artificiales» (ibid., p. 371). 
para la existencia de un nuevo organismo, no es condición suficiente. De allí que el criterio (b) no podría ser, por sí mismo, un argumento cierto para afirmar la existencia del organismo desde el momento de la fusión ${ }^{40}$. Por otro lado, añadiendo un nuevo elemento que en la discusión filosófica cobrará mayor relevancia, Austriaco tampoco acepta la equivalencia de la fusión con la fecundación porque la primera no produce de modo inmediato un nuevo organismo (con las características propias del cigoto). La fusión sólo inicia un proceso de reprogramación, no instantáneo, hacia un determinado estado epigenético ${ }^{41}$. Y así es como reafirma la hipótesis fundamental de los defensores de la ANT-OAR, a saber, que con la manipulación epigenética previa que efectúa esta técnica se impide que la célula producida artificialmente llegue en algún momento a la totipotencialidad propia de un nuevo organismo.

Finalmente Brugger se explaya algo más sobre la supuesta equivalencia funcional entre la fecundación y la fusión del núcleo con el óvulo enucleado -cuyos defensores llaman «fecundación imitada»- y su relación con el criterio (c) o la «procedencia remota» de los cromosomas paternos y maternos. De acuerdo con este autor, la introducción del núcleo en el óvulo enucleado no puede identificarse con una fecundación puesto que en ésta se unen dos células (gametos) con un núcleo diploide (23 cromosomas). Una vez que se produce la fecundación, ya en el cigoto, los núcleos provenientes de los gametos (espermatozoide y óvulo) se denominan «pronúcleos», y contienen todo el material genético del nuevo organismo, constituyendo un nuevo genoma distinto al del padre y la madre. Inmediatamente tras la fecundación comienza una interacción entre los pronúcleos y una serie de eventos biológicos que desencadenan el desarrollo embrionario. Con la primera división el genoma nuclear adquiere ya

40 Cf. N. Austriaco, «Altered Nuclear Transfer. A Critique of a Critique», Communio: International Catholic Review 32 (2005), pp. 172-176: p. 173. Austriaco agrega que la transferencia del genoma humano razonablemente completo no basta porque «[El] ovocito también tiene que ser capaz de reprogramar el genoma transferido, transformando aquel genoma en el que sólo se expresan los genes propios del tipo de célula del donante -por ejemplo una célula hepática- a otro donde sólo se expresen los genes asociados a un embrión humano unicelular. Este segundo evento -la reprogramación del genoma humano al estado epigenético asociado al embrión- es el evento esencial para la constitución de un nuevo organismo humano» (p. 174).

41 La no-instantaneidad, o el reconocimiento de que esta reprogramación es un proceso que lleva tiempo, es un hecho que ya se comprobó empíricamente con el test de pluripotencialidad realizado en ratones, ya descrito. 
la estructura y el aspecto característicos que poseerá en todas las células. En consecuencia, la diferencia entre los procesos de la fecundación y de la SCNT es evidente. En este último, lo que se fusiona no es ni un gameto ni una célula, puesto que el óvulo está enucleado. No habría, como Walker y Schindler afirman, ningún paralelo entre este procedimiento y una fecundación ${ }^{42}$.

Por último, adelantándose a una posible objeción de sus oponentes, Brugger señala que existirían dos formas de saber cuándo una célula es totipotencial o un cigoto humano. La primera sería a través de un análisis material, que consistiría en verificar si el patrón de expresión génica corresponde o no al estado de totipotencialidad. Al respecto hay que decir que la expresión génica de una célula totipotencial es un tema aún no resuelto por la ciencia. No se conocen todavía marcadores biológicos precisos para reconocer cuándo una célula es totipotencial, por lo que nos parece que este argumento no es, por ahora al menos, un criterio viable. La segunda forma sería a través de lo que él denomina un análisis temporal. Esto quiere decir, observando si su comportamiento de desarrollo es el mismo al de un nuevo organismo de esa especie ${ }^{43}$. Es lo que se comprobó por primera vez en la clonación de mamíferos con la oveja Dolly. Pero nuevamente, cuando se está hablando de seres humanos, esta forma de reconocimiento (que implicaría el riesgo de producir un clon humano) no es tampoco moralmente lícita. Los defensores de la ANT-OAR no renuncian al principio de cautela: resulta imprescindible comprobar primero en animales, con el mayor grado de certeza que la ciencia experimental pueda dar, que estas técnicas jamás podrían producir un nuevo organismo. Pero incluso así -dice Colombo- quedará siempre el problema de la extrapolación a humanos, por lo

42 Cf. C. Brugger, «ANT-OAR: A Morally Acceptably Means for Deriving Pluripotent Stem Cells. A Reply to Criticisms», Communio: International Catholic Review 32 (2005), pp. 753-769. Brugger ahonda en su crítica: «Si la ANT-OAR produjera un embrión humano, entonces la entidad creada tendría que estar, o pasar por, un estado epigenético de totipotencialidad. Pero el producto de la ANT-OAR nunca es totipotencial ni pasa por ese estado». Y apuntando particularmente a Schindler, quien señala que la ANT-OAR es una «concepción imitada» y no considera relevante si la célula producida es pluri o totipotente desde su inicio, o si requiere tiempo para serlo, ya que de todos modos sería un embrión, afirma: «Esto contradice las evidencias científicas. Un embrión unicelular es totipotente por definición» (pp. 762-763).

43 Ibid. 
que siguiendo el mismo principio de cautela esta técnica no sería nunca éticamente admisible ${ }^{44}$.

En resumen, la afirmación básica de los detractores de la ANT-OAR (criterio (a)) no se condice con la información científica. No existe «fecundación imitada»; y aunque hipotéticamente fusión y fecundación pudiesen considerarse como equivalentes, los criterios de reconocimiento (a) y (d) se excluirían (y por tanto, alguno sería falso). Como ya se comprobó empíricamente que la célula producida vía SCNT no es inmediatamente totipotencial, el criterio (a) vendría a ser el falso. Por otro lado, el genoma introducido al ovocito enucleado es «completo» (criterio (b)), pero no «nuevo», puesto que en cualquier SCNT el genoma nuclear es idéntico al de la célula somática del que procede (y no una combinación entre el DNA de los progenitores). De allí que la «procedencia remota» (criterio (c)) también parecería ser un eufemismo, debido a que de hecho se podría atribuir indistintamente a cualquier la célula del organismo con el número adecuado de cromosomas derivados del padre y la madre.

Por consiguiente, a la luz de los hechos anteriores, nos parece que las objeciones planteadas por los detractores de la ANT-OAR contienen errores biológicos de consideración. La evidencia científica muestra que la técnica de la SCNT, o alguna de sus modificaciones, implica un proceso que es muy distinto al que ocurre en la fecundación ${ }^{45}$. Por el contrario, la hipótesis esgrimida por los defensores de este procedimiento es más plausible, aunque para validarla habría que probar científicamente la factibilidad técnica de detener el proceso de des-diferenciación antes de llegar a una célula totipotencial o cigoto, lo que hasta la fecha no se ha realizado.

Con todo, cuando la información científica no es concluyente y su interpretación compleja, la bioética debe ayudarse con un análisis filosófico

44 R. Colombo, «Altered Nuclear Transfer as an Alternative Way to Human Embryonic Stem Cells: Biological and Moral Notes», Communio: International Catholic Review 31 (2004), pp. 645-648: p. 646. «Por último - dice- pero no menos relevante, lo que aquí está en juego [i.e. la vida de un ser humano] es algo tan importante que, desde la perspectiva de la obligación moral, la mera probabilidad de que en el proceso de la ANT se vea implicado un embrión humano basta para justificar una prohibición clara y absoluta del uso de esta biotecnología (cf. JuAn PABLo II, Evangelium Vitae, 60)».

45 No se puede afirmar que un nuevo organismo comienza con el proceso de des-diferenciación que se inicia al momento de la fusión del núcleo somático con el óvulo enucleado. Lo propio de un nuevo organismo es su capacidad integrada para desarrollarse a través de un proceso de diferenciación y organización. 
para alcanzar, como urgentemente requiere, algún marco de referencia desde el cual evaluar los hechos empíricos. La decisión ética sobre qué línea de investigación seguir no es sólo materia de la ciencia; y la reflexión filosófica, que amplía la perspectiva, puede enriquecer significativamente la discusión. La gran pregunta filosófica que se plantea en este caso, y la que va a contribuir a establecer parámetros más ciertos para identificar organismos humanos unicelulares, será: «¿Qué es lo que determina, y cómo se reconoce, la naturaleza de algún ser?».

\subsection{Desde la filosofía}

Un organismo humano producido de forma artificial es un «organismo», una sustancia viva, completa, que posee su propio principio interno de movimiento, el cual lo dirige hacia su perfección natural ${ }^{46}$. Pero, simultáneamente, de acuerdo con las definiciones de la filosofía clásica, es también un «artefacto», un ente fabricado por un artífice que une materiales (el núcleo de una célula diferenciada y el ovocito enucleado) en vistas a «producin» otra cosa. Cuando no existía la posibilidad de la producción artificial de organismos, estas categorías filosóficas (sustancias vivas naturales y artefactos) bastaban para discernir entre distintos tipos de entes y la licitud de su manipulación. Pero esta tercera posibilidad, un organismo que tenga como causa eficiente a un técnico - una suerte de «organismo artificial» - cae fuera de dichas categorías y dificulta con mucho su análisis.

Indudablemente, con el paso del tiempo la bioética tendrá que ampliar su marco metafísico para hacer frente a los desafíos que le están planteando la biotecnología y bioindustria. Sin embargo, en el debate que comentamos las categorías filosóficas utilizadas fueron básicamente aristotélicas (forma, materia, acto, potencia, etc.), y aunque ellas resulten insuficientes para dar razón clara y definitiva del problema concreto de la SCNT, siguen siendo útiles -especialmente de modo negativo, es decir, para evitar la contradicción- en vistas a encontrar puntos de referencia éticos, racionalmente justificables, respecto de problemas más específicos como la producción de CME por medio de la ANT-OAR.

Muy resumidamente, y como ya se ha aludido, para Aristóteles existían las sustancias naturales y los artefactos, ambos constituidos por «forma» y «materia». Para explicar esta composición el filósofo griego solía poner

46 N. Austriaco, «The Moral Case for ANT-derived Pluripotent Stem Cell Lines», Natl Cathol Bioeth Q. 6 n. 3 (2006): pp. 517-37. 
ejemplos tomados del ámbito de la producción técnica, que luego extrapolaba, en la medida de lo posible, a las sustancias naturales ${ }^{47}$. Es así como en la «estatua de Apolo» la forma es la imagen de este dios, mientras que la materia es el bronce del que está constituido. La «forma», en este caso, se la da el escultor, quien también decide entre las diversas «materias» apropiadas para su escultura: bronce, madera, oro, etc. La relación forma/materia en los artefactos, entonces, es totalmente extrínseca. Respecto de las cosas naturales, la «forma» es la que hace que tal ente sea un ejemplar de su correspondiente especie, con características compartidas con los otros ejemplares y transmisibles a través del proceso de reproducción (la «forma», en este caso, no la elige un artífice, sino que se transmite directamente desde otro ejemplar de esa misma especie); y la «materia» tampoco es aleatoria sino que «viene, de algún modo, dada de antemano (cf. Fís. II 2, 194b78). En efecto, las formas de las cosas naturales sólo pueden realizarse en una materia determinada... $\rangle^{48}$ La relación forma/materia por tanto, en las sustancias naturales, es intrínseca; no existen por separado ni hay más posibilidades de las que ya vienen dadas y transmitidas vía reproducción.

\subsubsection{El «comienzo absoluto» de un nuevo organismo}

Volviendo al debate acerca de la ANT-OAR, José Granados es otro participante que se opone a esta técnica señalando que el «comienzo absoluto» de un nuevo organismo producido por SCNT es el momento de la fusión del núcleo con el óvulo enucleado. Él se explaya en un hecho del cual tiene razón: el organismo, como se sabía incluso antes de conocer empíricamente la fecundación, debe tener un inicio, tiene que existir un evento en el que comience a existir y se genere todo el proceso de la embriogénesis; un instante en el que el cigoto se constituya para proseguir luego, a través de un desarrollo continuo, hacia su plenitud. Este desarrollo contiene fases, pero en ningún momento se detiene o interrumpe con otro evento que cambie la naturaleza sustancial de la célula haciéndola pasar de no-organismo a organismo ${ }^{49}$; de un mero artefacto biológico a un ser perteneciente a nuestra especie.

47 Cf. A. Vigo, Aristóteles..., pp. 72-73. En general, en este autor nos apoyaremos para las precisiones de la doctrina aristotélica.

48 A. Vigo, Aristóteles..., p. 73.

49 Este argumento sí es esgrimido, en cambio, por quienes niegan la calidad de persona al embrión, arguyendo algunos que tras la fecundación sólo hay «un conjunto de células». 
Granados da un paso más allá de Walker y Schindler, haciéndose cargo de la objeción de Austriaco respecto de que la fusión no produce de modo inmediato una célula en el mismo estado epigenético asociado a la totipotencialidad del cigoto. Él reconoce que la des-diferenciación es un proceso que tiene cierta duración hasta llegar al estado de totipotencialidad. Sin embargo su tesis es que igualmente el nuevo organismo se crearía en el momento de la fusión, con la única diferencia de que en estos casos artificiales el desarrollo del organismo incluiría, en su comienzo, una etapa de des-diferenciación previa a la totipotencialidad, tras la que seguirían todas las otras características del proceso natural de la embriogénesis ${ }^{50}$. El estado de totipotencialidad no sería un evento capaz de cambiar la naturaleza sustancial de la célula (convirtiéndola en embrión humano) sino sólo una etapa más, análoga a todas las demás. La transferencia del núcleo -dice Granados- sería el único evento en el que hay verdaderamente un cambio sustancial o de la naturaleza del ente, razón por la que constituye el «comienzo absoluto» del nuevo organismo. Tras éste no hay nada que interrumpa la continuidad del proceso, por lo que aquella célula sigue siendo el mismo ser en todo momento: un ser humano. En consecuencia, los cambios epigenéticos no alterarían la naturaleza de la célula sino que únicamente detendrían el desarrollo del embrión, como habría sucedido en el caso de la ANT con silenciamiento del Cdx2 ya descrito.

Ahora bien, señalar que la totipotencialidad es un punto artificial y arbitrario para situar el inicio del organismo, como dice Granados, ya que no hay ningún evento externo (ajeno a la naturaleza de la célula) que detenga un proceso para dar inicio a otro ${ }^{51}$, invita a preguntarse si es posible que un ente cambie su naturaleza ( $\mathrm{y}$ pase de un proceso a otro) sin mediar una causa externa. Pues bien, de este tipo de acontecimientos sí existe un ejemplo muy común: la muerte. Cuando un organismo vivo

50 Cf. J. Granados, «ANT-OAR: Is its Underlying Philosophy or Biology Sound?» Communio: International Catholic Review 32 (2005), pp. 724-743. En la p. 737 dice: «La reprogramación, una vez que ha empezado con la SCNT, es un paso necesario de un proceso único que concluirá, teóricamente, con el nacimiento de un niño. ... La dinámica de la célula en estos primeros momentos de reprogramación ya tiende a posibilitar la formación completa de un ser humano. La actividad misma de reprogramar expresa la existencia actual de un sistema que funciona en vistas a un objetivo único. Establecer que sólo hay organismo humano en el momento en que se ha alcanzado la totipotencialidad, pero no antes, parece algo artificial y arbitrario. ... [ La fusión] es el evento y punto de inicio que gatilla todo el proceso».

51 Cf. J. Granados, «ANT-OAR: Is its Underlying....», p. 737. 
ha completado su proceso de desarrollo, ha alcanzado la plenitud o su telos natural (o no lo ha alcanzado porque padece algún tipo de disfunción incompatible con la vida), simplemente muere; y deja de ser un «cuerpo» y pasa a ser un «cadáver». Deja de ser organismo y se convierte en materia desorganizada. Hay allí un evento, un punto de quiebre en el proceso: la muerte cambia la naturaleza del ente; el organismo deja de ser lo que era y empieza a ser otra cosa.

Por tanto, si la dirección del proceso biológico de la célula creada por la SCNT es la des-diferenciación o des-programación del núcleo de la célula especializada del donante, éste llega a término cuando se ha borrado totalmente su identidad original (por ejemplo, una célula hepática) y ha alcanzado el estado de una célula totipotencial. Ése sí es un evento, la compleción del telos (el fin al que todo ese proceso iba dirigido); la desaparición de una naturaleza y su transformación en otra cosa. Es un evento que, como la muerte, pone término a un proceso e inicia uno distinto. ¿Cuál, en este caso? Como la célula totipotencial se identifica con un cigoto, puesto que en su totipotencialidad contiene la capacidad de desenvolverse hasta el estado adulto, el proceso que inicia es el de la embriogénesis, caracterizada por la diferenciación (que es lo contrario a la des-diferenciación del proceso anterior) y el desarrollo ordenado hacia otro telos: la plenitud de una naturaleza humana, el crecimiento gradual hacia la adultez. Una vez alcanzado este telos, el nuevo ente morirá, convirtiéndose ahora en cadáver, materia en des-composición (lo contrario a la «composición» creciente del organismo).

Ésta, que es nuestra primera crítica a Granados, complementa la que hizo Brugger a los detractores de la ANT-OAR afirmando que su tesis no era consistente con la evidencia científica. En la fusión no puede producirse un nuevo organismo puesto que lo que ella inicia es un proceso de des-diferenciación del núcleo insertado, lo que no es identificable con la diferenciación del desarrollo cigótico. Por el contrario, de lo que se trata es de reprogramar el núcleo de una célula altamente diferenciada a un estado pluripotencial sin alcanzar nunca el de la totipotencialidad. Este proceso se asemejaría más a alguna técnica capaz de reprogramar una célula somática especializada haciéndola regresar a un estado pluripotencial, como Hurlbut lo subrayaba cuando proponía la ANT-OAR ${ }^{52}$.

52 Cf. W.B. Hurlbut, «Altered Nuclear Transfer...», Por otro lado, en el tiempo en que ocurrió el debate en la revista Communio no se habían publicado los experimentos 
Todavía hay dos comentarios que se pueden agregar en este punto. El primero es la gran diferencia que existe entre intervenir en el camino de una célula que está en proceso de des-diferenciación y que por lo tanto todavía no ha sido nunca totipotencial, i.e. no ha sido nunca un cigoto humano; e intervenir en el desarrollo de otra célula que ya comenzó su diferenciación y embriogénesis, lo que equivale a interrumpir la vida de un ser humano. Esta diferencia es fundamental a la hora de evaluar la legitimidad moral de la ANT-OAR. Con todo, la distinción no es un contra-argumento válido para los detractores de la ANT-OAR ya que implica un supuesto que ellos no aceptan: que las etapas de des-diferenciación no forman parte de las del desarrollo embrionario (y la crítica se podría acusar de circularidad). Sin embargo, la distinción es tan importante que vale la pena anotarla.

El segundo comentario sí podría invalidar la tesis de los oponentes a este procedimiento. Ellos afirman que no tendrían objeción moral frente a una técnica que sólo hiciera «regresan» una célula somática adulta al estado de pluripotencialidad ${ }^{53}$. Pero, según había dicho Brugger, el núcleo de la célula somática se inyecta en «algo» que no es ni siquiera una célula, sino sólo una «bolsa de citoplasma» ${ }^{54}$. De acuerdo con esto, y sin forzar demasiado la interpretación, se podría incluso argüir que esa «bolsa de citoplasma» se limita a ser un mero instrumento de reprogramación, frente a lo cual los oponentes del ANT-OAR quedarían obligados a aceptarlo. En otras palabras, la segunda hipótesis del proceso que haría la ANT-OAR es que el citoplasma del óvulo realizaría la reprogramación sólo hasta el estado pluripotencial, en forma semejante a lo que logró Yamanaka inyectando genes o factores que reprograman la célula somática a ese estado (ver Figura 3).

que han demostrado que esta técnica sí es posible (cf. K. TAKAHASHI y S. YAmANAKA (2006), ya citado).

53 Cf. A. Walker, «Altered Nuclear Transfer: A Philosophical Critique», Communio: International Catholic Review 31 (2005), pp. 649-684. Este autor dice que la ANT ha sido explícitamente propuesta como una «solución tecnológica ante un impasse moral»; es decir, una forma inmediata (o «de emergencia») para enfrentar un estancamiento político. Y con el término «inmediata» se refiere a que la ANT se basa en técnicas ya existentes de transferencia nuclear, y no en técnicas deseables pero aún no existentes como podría ser la regresión de células somáticas adultas a un estado pluripotencial (p. 665).

54 C. Brugger, «ANT-OAR: A Morally...», p. 762. 


\subsection{2 ¿Qué determina la naturaleza de una célula: la genética o la epigenética?}

Como ya hemos visto, en su primer artículo crítico Walker destaca que la naturaleza de la célula producida vía SCNT está dada por la posesión de un genoma humano ${ }^{55}$. Su intención básica es afirmar que el organismo se crea en la fusión misma del núcleo somático con el ovocito enucleado (criterio (a)), y que las determinaciones epigenéticas posteriores, que van reprogramando esta célula hacia el estado de totipotencialidad presuponen la posesión de ese genoma. Su argumento, en definitiva, busca exaltar la prioridad ontológica del organismo (que identifica con la posesión del genoma) sobre sus estados epigenéticos. La existencia de ese genoma sería la condición necesaria básica e ineludible para establecer el estatus de organismo humano, mientras que todos los otros factores sólo son condiciones para mantenerlo una vez que éste ya se ha constituido ${ }^{56}$. La naturaleza del organismo, entonces, se imprimiría en la fusión: Allí es donde se crea al «sujeto ontológico», el sustrato que se reprograma desde sí mismo hacia el estado epigenético del cigoto ${ }^{57}$.

Para aclarar este punto, hay que recordar que la naturaleza, según la definición aristotélica, es «un cierto principio y causa del moverse y del permanecer en reposo en aquello en lo cual está presente primariamente, por sí mismo y no por accidente (Fís. 193b21-23) $\rangle^{58}$. Alejandro Vigo señala que esta caracterización contiene tres elementos: la naturaleza es causa; es causa del movimiento y el reposo; y es inmanente al correspondiente objeto, algo que lo constituye como tal. Así, lo que Walker afirma cuando dice que la epigenética muestra que el desarrollo está ocurriendo

55 Cuando se hable aquí de «naturaleza» ya se estará usando el término en su sentido metafísico, es decir, el núcleo entitativo más propio de un objeto particular o de un grupo de objetos particulares.

56 Cf. A. Walker, «Altered Nuclear...», p. 664. También dice: «Por cierto no estoy sugiriendo que el genoma sea el único factor relevante en la antropogénesis. Sólo digo que la constitución de un nuevo genoma humano señala el comienzo absoluto del proceso de desenvolvimiento que sólo un organismo ya existente puede realizar, mientras que todo evento posterior a la constitución de ese genoma se debe comprender como una fase dentro de dicho proceso». En estas afirmaciones, sin embargo, Walker comete el error científico ya hemos destacado.

57 A. Walker, «Reasonable Doubts: A Reply to Christian Brugger», Communio: International Catholic Review 32 (2005): p. 774. En la próxima sección, sin embargo, veremos que «sujeto ontológico» (organismo humano) y «sustrato» no son exactamente lo mismo, como Walker estaría identificando.

58 A. Vigo, Aristóteles..., p. 69. 
pero la genética muestra que el desarrollo es posible, vale decir, que «hay ya un ser capaz de desarrollo» ${ }^{59}$, es que la célula producida (organismo humano, según él) es la causa de sus diversos estado epigenéticos. Por consiguiente, la epigenética no tendría ningún poder constitutivo, y no cabría identificar la presencia de un nuevo organismo humano por su estado epigenético, que para los promotores de la ANT-OAR equivaldría al de una célula totipotencial.

En la misma línea Schindler critica la sobre-importancia que se estaría dando a la epigenética para determinar la naturaleza de una célula (y con ello establecer que lo que hace que el cigoto sea cigoto es la totipotencialidad, asociada a determinada activación de genes). Según éste, la epigenética no puede nunca ser la causa primera de un organismo sino sólo la expresión de un ser orgánico ya existente, cuyo origen tiene que buscarse en una producción instantánea y completa llamada «concepción». La epigenética no puede ser constitutiva; sólo determina la manifestación fenoménica de una célula cuya identidad ontológica o sustancial ya está dada. La actualidad del organismo es ontológicamente previa a la actividad coordinada de sus partes ${ }^{60}$. Por tanto, señala Schindler, intervenir en el proceso de des-diferenciación (en el que ya habría un organismo constituido) no cambiaría la identidad sustancial de la célula sino que sólo bloquearía su reconocimiento ${ }^{61}$.

Frente a estos sólidos argumentos -los genes indudablemente son ontológicamente previos a su activación-, quienes se inclinan por priorizar la epigenética (o la identificación del embrión con la célula totipotencial) matizan su postura, aceptando que si bien el estado epigenético no determina la identidad ontológica de la célula (no la constituye en organismo), sí es una

59 A. WALKER, «Altered...», p. 664.

60 Cf. D. Schindler, «A Response to the Joint Statement: «Production of Pluripotent Stem Cells by Oocyte Assisted Reprogramming'», Communio: International Catholic Review 32 (2005): p. 375.

${ }^{61}$ Cf. D. Schindler, «Veritatis Splendor and the Foundations of Bioethics: Notes towards an Assessment of ANT and Embryonic (Pluripotent) SC Research», Communio: International Catholic Review 32 (2005), pp. 195-201. «En resumen, dice, la ANT (en todas sus formas conocidas) impide el reconocimiento de la naturaleza propia del ser y del actuar de un organismo en sus expresiones más sutiles y momentos más vulnerables, en la medida en que éstos implican más de lo que se puede explícitamente conocer en términos empíricos y mecánicos, y por tanto en la medida en que ellos implican un misterio» (p. 199). 
condición necesaria para la actualización de la vida embrionaria ${ }^{62}$. Entonces, sin alcanzar el estado epigenético asociado a la totipotencialidad nunca podría actualizarse la vida del embrión, es decir, nunca llegaría a existir el embrión. De ahí que sin negar la prioridad ontológica del organismo, sí puede asociarse a éste, en su momento constitutivo, un cierto estado epigenético que es el requerido para que tal organismo exista; concretamente, el que corresponde a la totipotencialidad. Así, la epigenética sí vendría a ser una señal cierta de su constitución; un signo que permite reconocer al organismo complejo pluricelular cuando está en su estado inicial unicelular ${ }^{63}$.

Este punto de la discusión deja al descubierto un gran error en este debate, en el que parecería haber una suerte de competencia entre la importancia de la genética y de la epigenética. Dicha pregunta está mal planteada. Si la epigenética es la activación o silenciamiento de genes requiere, obviamente, que existan esos genes. Pero, por otro lado, cuando un gen existe, está, necesariamente, activado o silenciado, i.e. en algún estado epigenético peculiar. Vale decir, no puede existir genética sin epigenética, ni tampoco lo contrario. Al preguntar, entonces, qué determina la naturaleza de una célula, no tiene sentido ponerlas como alternativas excluyentes. Es por esto que Michel Morange ha dicho, con toda razón según nuestro entender, que el verdadero «triunfo de la epigenética» se dará cuando el término mismo desaparezca o, mejor, cuando la epigenética se integre con la genética clásica en lo que podría denominarse una «nueva genética» ${ }^{64}$.

El estado epigenético de una célula, como ya hemos dicho, determina qué tipo de célula es. Ahora bien, sólo el estado asociado a la totipotencialidad puede dar una señal cierta de que esa (única) célula es un organismo,

62 Brugger, C.: «ANT-OAR: A Morally...», p. 758.

63 Cabe resaltar de que se habla de señal cierta, de signo; vale decir, el estado epigenético no constituye al organismo sino que sólo es el que permite reconocerlo. Y en este punto también es necesario recordar que en la actualidad no existen marcadores biológicos para reconocer a una célula en estado totipotencial; en otras palabras, a pesar de tener un criterio de reconocimiento, éste no es aún aplicable empíricamente. Pero ello no obsta para la importancia de esta dilucidación. Aunque esta discusión se esté dando en nivel teórico, no es por eso menos útil ni importante para sus conclusiones prácticas.

${ }^{64}$ Morange, M.: «The Relations between Genetics and Epigenetics: A Historical Point of View», Ann N Y Acad Sci. 981 (2002): pp. 50-60. «Cuando sea posible integrar la información de ambas esferas, sospecho vivamente que la epigenética como tal va a desaparecer, porque las ideas epigenéticas estarán presentes en todas las prácticas e ideas de los genetistas. Su desaparición será el verdadero signo de su victoria». 
puesto que sólo una célula toti-potencial «alberga todas las instrucciones necesarias para constituir el cuerpo humano, que contiene alrededor de 100 trillones $\left(10^{14}\right)$ de células - una hazaña asombrosa» ${ }^{65}$. La totipotencialidad es condición necesaria para que exista un embrión con todas las instrucciones requeridas para que en su desarrollo vaya orientando y diferenciando sus células para estructurar los distintos tejidos y órganos que tienen, cada cual, sus células específicas.

Por tanto, en nuestra opinión, es claro que la formación de un nuevo organismo en el proceso de la SCNT no es inmediata: no basta la fusión del núcleo con el óvulo enucleado sino que deben darse las condiciones biológicas precisas para la actualización de la vida embrionaria. Asimismo, y aunque no cabe separar a la genética de la epigenética, puesto que la identidad genómica y la identidad epigenética de un ser están intrínsecamente conectadas, sí cabe resaltar que al hablar del «estado epigenético de una célula» se está hablando de la totalidad pre-programada del estado «activado», «silenciado» o «para-ser-activado» de los genes del genoma ${ }^{66}$; en otras palabras, de la determinación de las potencialidades de tal célula. Y como toda célula humana requiere un conjunto específico de potencialidades para llevar a cabo el proceso autodirigido del desarrollo orgánico, si una célula contiene esas potencialidades en su determinación epigenética primordial (la totipotencialidad), y no sólo si tiene un genoma humano, es un embrión humano. Caso contrario, no lo es ${ }^{67}$.

\subsection{3 «El obrar sigue al ser»}

Pero hay todavía otro tema que se ha discutido y que tiene gran importancia para la determinación de los criterios que permitan reconocer al embrión unicelular; aunque, a su vez, toca uno de los problemas metafísicos más complejos que no podremos discutir hasta la próxima sección.

Quienes defienden la primacía de la epigenética (o que el organismo humano se constituye sólo tras haber llegado al estado de totipotencialidad) se apoyan también en la doctrina aristotélica que dice que algo es lo

65 H. Lodish, A. Berk, y otros, Molecular Cell Biology, W. H. Freeman \& Company 6th edition, 2008. Énfasis nuestro.

${ }^{66}$ Cf. C. Brugger, «ANT-OAR: A Morally...», p. 759.

${ }^{67}$ El sustrato material del organismo producido artificialmente debe, como es obvio, estar constituido con la materia apropiada para que el organismo exista; en este caso, principalmente, debe tener un genoma humano. Sin embargo, la mera posesión del genoma no lo convierte en organismo. 
que es por su esencia ${ }^{68}$, la que en los seres naturales incluye tanto la forma como la materia ${ }^{69}$. La «forma» vendría a ser «la actualidad de un cuerpo natural que posee la vida en potencia» (De Anima II.1 412a27). Este «poseer la vida en potencia» significaría que el sustrato material, en el caso del organismo humano, debe tener la capacidad de ser actualizado para vivir del modo específicamente humano («obran» como tal, en cuanto tiene forma humana y «el obrar sigue al ser»). El sustrato no puede ser una bola de mármol ni un trozo de madera, sino una materia determinada en una determinada disposición. En otras palabras, sólo el material orgánico dispuesto del modo apropiado para el desarrollo humano puede llegar a ser un ser humano.

Por consiguiente, el fondo de este argumento señala que sólo puede haber organismo humano allí donde hay una unidad discreta de materia orgánica que se comporta como organismo humano. Y esa unidad de materia, que en este caso es una célula cuyos componentes materiales efectivamente son los de una célula humana, sólo empieza a comportarse como organismo humano cuando es totipotencial e inicia el proceso de la embriogénesis. Sólo en ese instante aquella célula que materialmente había comenzado a existir con un núcleo diferenciado, y que en sus diversas fases de des-diferenciación fue pasando por distintos estados epigenéticos, aunque ninguno de ellos análogo al de un organismo humano en su momento constitutivo, puede identificarse con un organismo humano unicelular. El material orgánico es el sustrato, pero éste no basta para que una célula sea organismo humano (como el mármol de la estatua de Apolo no basta para que exista la estatua); se requiere también una «forma» humana. ¿Y cuál es o qué es esa forma? ¿O cómo se adquiere esa forma? Algo intentaremos decir en lo que sigue, mas por ahora baste con afirmar que la totipotencialidad y el estado epigenético asociado a ella manifiestan la existencia de

${ }^{68} \mathrm{La}$ «naturaleza», para Aristóteles, es la misma «esencia» en cuanto principio de operaciones.

69 Lo mismo sucede en los artefactos, como ya vimos, pero de un modo distinto. Además, según afirma Vigo, para Aristóteles la noción de «naturaleza» (en objetos naturales) se debe entender, en sentido primario, como la forma del objeto natural y no su materia, la cual sólo puede ser considerada como naturaleza del objeto en un sentido derivativo y secundario (cf. Fís II 1). La importancia de esta afirmación se comprenderá cuando nos ocupemos de la relación forma/materia del organismo; sin embargo, en esta sección, sólo trataremos el punto de que «si existe tal forma, existe tal obrar». 
esa forma, lo que equivale a decir que aquella unidad discreta de materia orgánica es un organismo humano, como antes no lo era.

Sin embargo, quienes se inclinan por el criterio genético desacreditan esta interpretación de Aristóteles. Ellos señalan que precisamente lo que la ANT realiza es alterar la manifestación de las potencias del organismo, pero con ello no evitan crear organismos humanos sino que sólo crean organismos (embriones) defectuosos ${ }^{70}$. Las potencias - afirman- inhieren sobre naturalezas ya actuales, y no al revés. Para que exista una potencia, debe antes haber un acto. «Algo» tiene que «ser actualmente» para poder tener la potencia de realizar alguna acción. Y si esas potencias no están, puede ser por dos razones: o bien ese «algo» no es de la naturaleza que habitualmente posee esas potencias (en este caso, no es un organismo humano); o bien ese «algo» sí es de la naturaleza que habitualmente posee esas potencias pero en ese ejemplar concreto no las manifiesta porque es un ejemplar defectuoso (es un organismo humano, pero con un defecto). El problema, entonces, de tomar a la potencia (i.e. a la toti-potencialidad) como criterio para determinar la existencia del organismo, es que no permite diferenciar entre no-embriones y embriones defectuosos. En otras palabras, los «epigenetistas» darían vuelta el principio metafísico aristotélico para afirmar, falazmente, que «el ser sigue al obrar» ${ }^{71}$.

Pues bien, estos autores no se equivocan al afirmar que el acto es anterior a la potencia, que el obrar sigue al ser y que se puede dar el caso de que no haya «obrar»-por algún defecto en el ejemplar-y sin embargo sí haya ser. El obrar manifiesta al ser, pero no lo constituye como tal. No obstante, también es cierto que dado el horizonte cognoscitivo de los seres humanos, sólo accedemos a la realidad a través de los sentidos; es decir, sólo podemos conocer las «manifestaciones» de un ser (en términos amplios: su estructura y su actividad). Si un ente determinado no tiene la estructura material propia de su especie (por ejemplo, un genoma humano razonablemente completo) ni se comporta en al menos alguna de sus fases de desarrollo como los organismos típicos de su especie (por ejemplo, un cultivo de células no se comporta en ningún momento como un embrión), no cabría decir que estamos en presencia de un organismo de esa especie (un ser humano). Por esto dice Brugger que si «el comporta-

\footnotetext{
70 A. Walker, «Reasonable Doubts...», p. 777; Schindler, D.: «Veritatis Splendor...», pp. 195-196.

71 A. Walker, «Reasonable Doubts...», p. 778.
} 
miento de una célula no es conmensurable con el del embrión, esa célula no es un embrión» ${ }^{72}$.

En consecuencia, si bien es cierto que existen ejemplares defectuosos (no poseen alguna(s) de la(s) potencias activa(s) propias de su especie), cuando un ente no posee ninguna de dichas potencias (ni siquiera la capacidad de generar su estructura en alguna fase de su desarrollo), simplemente no se está frente a un ente de dicha naturaleza. Entonces, concediendo la prioridad ontológica del organismo sobre su «obran», se puede seguir manteniendo la tesis de Brugger de que, para que algo sea considerado un embrión humano es condición necesaria que se encuentre en la disposición provista por el estado epigenético en que se encuentra la célula totipotencial ${ }^{73}$.

\section{Organismo bumano unicelular: hacia un marco orientativo}

El objetivo central de este debate, en el que ha interactuado ciencia y filosofía, era identificar criterios para reconocer a un embrión humano unicelular producido artificialmente pero no por fecundación. Es interesante que los pioneros en la clonación de animales ya se preguntaran cuándo, en la reprogramación, se alcanzaba la totipotencialidad de la célula inter-

72 C. Brugger, «ANT-OAR: Morally...», p. 764. Dice también que para que un ente pueda ser identificado como un embrión debe «obrar» como tal: dividirse, diferenciarse, expresar los patrones bioquímicos propios de los embriones humanos. Éstos son los tests material y temporal que ya habíamos señalado, pero que empíricamente, por razones éticas, no se pueden aplicar. En el ámbito de la filosofía, en cambio, este argumento tiene una importancia central para inferencias posteriores.

73 Todas las células del organismo, como ya dijimos, tienen el mismo genoma pero se distinguen por su estado epigenético, el que determina, de acuerdo con qué proteínas sintetice, etc., su función. Esa «función» implica su «capacidad de realizarla», esto es, la célula epidérmica tiene la potencia de estructurarse como tal debido a su estado epigenético; pero la célula epidérmica no tiene la potencia de estructurarse como célula lipídica, ni de ningún otro tipo. La «materia» que constituye dicha célula debe estar dispuesta de tal modo como para que ella ejecute su función; en otras palabras, debe ser capaz, en primer término, de poder disponerse así (tener los genes necesarios) y, a la vez, de disponerse así (poder activar o silenciar los genes necesarios, según las «instrucciones» que el organismo como un todo le da, naturalmente). Pues bien, la célula que constituye al organismo humano unicelular está compuesta por una materia «dispuesta» del modo requerido como punto de inicio de la embriogénesis, y esa «disposición» es la que se revela en el estado epigenético asociado a la totipotencialidad. 
venida: si ocurría de inmediato o $\mathrm{no}^{74}$. Se trata de un tema muy complejo que la ciencia no ha dilucidado del todo pero que incide de modo directo en la discusión bioética actual. Tal vez, como pensamos, todavía no es el momento de buscar esos criterios definitivos de identificación, sino que hay que comenzar más modestamente, intentando primero dar un marco orientativo, un marco de referencia que, mientras la ciencia no permita reconocer con precisión el estado epigenético de la totipotencialidad, sí pueda ayudar a orientarse en las decisiones éticas frente a procedimientos que eventualmente involucren organismos humanos unicelulares. Esto es lo que haremos a continuación, profundizando en algunos de los argumentos esgrimidos pero desvinculándolos de la discusión concreta acerca de la ANT-OAR. Los dos conceptos en los que nos centraremos -que aunque intrínsecamente unidos pueden analíticamente separarse- son los de teleología y potencialidad.

\subsection{Forma, desarrollo y plenitud}

La teleología natural de un organismo viene dada por su naturaleza, y se refiere a la dirección de su desarrollo hacia su telos -su fin, plenitud o perfección- que está inmanentemente presente desde su inicio. La teleología de todos los ejemplares de una especie es, naturalmente, la misma; puesto que su desarrollo, la actualización de sus potencias, la aparición de aquellas características que permitirán identificarlo como un ser de tal especie y no otra, es la misma. Todos los perros, cuyo inicio absoluto está en la fecundación, se van desarrollando del mismo modo durante la embriogénesis, diferenciando tejidos, estructurando y organizando su cuerpo hasta nacer. Posteriormente prosiguen su crecimiento continuo, aumentan su tamaño, comienzan a ladrar, etc., hasta llegar a la adultez (su telos). Ningún perro se desarrolla como gato. Todos tienden de igual manera hacia el mismo fin; y si por alguna razón su vida se interrumpiera antes de alcanzarlo, mientras estuvieron vivos su desarrollo era el mismo, llevaba la misma dirección que cualquier otro ejemplar de su especie en ese mismo estadio de crecimiento. Pues bien, como hemos dicho, la especie o el «tipo de ser» de un ente viene dado por lo que Aristóteles llamó «forma sustancial». Todos los perros tienen la misma forma, y por eso se desarro-

74 Cf. J. Gurdon y otros, «Nuclear Reprogramming in Eggs», Nat Med. 15 n. 10 (2009): pp. 1141-1144. Su estudio sugiere que en sapos y mamíferos esto ocurriría, respectivamente, entre 5 y 20 horas tras la fusión, cuando se aprecia el inicio de la expresión de nuevos genes en el núcleo transferido. 
llan del mismo modo. La forma es «el principio que regula y orienta dicho proceso de generación y crecimiento, [y] puede decirse que, en el caso de seres naturales como los seres vivos, la materia misma está sujeta al poder configurador de la forma: es, pues, la forma, como principio configurador activo, lo que garantiza la unidad y persistencia del compuesto orgánico, con su peculiar configuración material y la correspondiente configuración de sus partes» ${ }^{75}$.

En el ámbito netamente empírico, la teleología natural de cualquier viviente sólo se puede conocer a través de la observación de las características y el desarrollo de otros individuos normales de la misma especie; vale decir, a posteriori. Así sabemos, por ejemplo, que el telos natural de una bellota es ser un roble plenamente desarrollado, con las peculiaridades propias del roble (tipo de hojas, fases de desarrollo, tiempo de crecimiento, etc.). Y esa teleología natural no varía ni aunque la bellota esté sobre una mesa y jamás llegue a ser roble, ni aunque por algún defecto orgánico o condición ambiental muera antes de alcanzar su plenitud.

¿Y cuál es la teleología natural, la dirección de desarrollo, de un organismo humano? Es la de un adulto plenamente desarrollado que llega a ser tal a través de un proceso que se inicia en la embriogénesis y continúa en la infancia, juventud, etc., adquiriendo paulatinamente las características propias del adulto normal. Ése es su «movimiento natural»; que realiza por sí mismo (naturaleza como causa del movimiento) en virtud de sus propias características y de las tendencias conectadas con ellas. La realidad de los procesos que caracterizan a los distintos tipos de seres vivos sólo pueden explicarse por referencia a los aspectos de potencialidad que entran en la constitución de estos entes; las virtualidades que albergan en sí, que vienen ya contenidas en su en su forma ${ }^{76}$.

Ahora bien, para la presente discusión el lapso que hay que examinar es el de la embriogénesis, sus fases y direccionalidad. Aquí es claro que lo propio del embrión humano es la diferenciación, organogénesis, división y multiplicación de células, etc. No forma parte de ella una des-diferenciación nuclear en ésta ni ninguna otra fase de su vida. En consecuencia, y como lo que caracteriza a la célula producida vía SCNT es precisamente la des-diferenciación o des-programación del núcleo especializado que se le introdujo, puede decirse con toda justificación que, al menos mientras

\footnotetext{
75 A. Vigo, Aristóteles..., p. 74.

76 Cf. A. Vigo, Aristóteles..., p. 69.
} 
dura ese proceso, allí no hay un embrión humano. Hay una célula, viva, organizada, pero que se mueve en la dirección exactamente opuesta a la del desarrollo de un organismo humano: no es un individuo de nuestra especie. No obstante, cuando esa célula alcanza la compleción de ese proceso y llega a ser una célula totipotencial, sí comienza un proceso igual al de la embriogénesis natural. Entonces, y sólo entonces, ya habría un nuevo organismo humano, una persona. El proceso de des-diferenciación nuclear, por el que idealmente se llegaría a un estado de totipotencialidad, es la «dirección de desarrollo» propia de la célula intervenida, la actualización progresiva de sus propias virtualidades que, evidentemente, difieren de las de un organismo humano. No se puede decir que es una célula con «forma» humana (una persona).

Anteriormente vimos que Granados cuestionaba el hecho de que sólo en el momento de llegar a la totipotencialidad la célula artificial cambiara su naturaleza para convertirse en organismo humano. Su argumento central era que ésta era organismo humano desde el principio, pero cuya «teleología natural» comenzaba con la des-diferenciación hasta llegar a la totipotencialidad, para luego continuar con un proceso de diferenciación. Cada uno de estos procesos serían sólo fases de un desarrollo continuo. La totipotencialidad, de acuerdo con este autor, no constituiría un nuevo evento que diera inicio a otro proceso y produjera un cambio sustancial.

En su argumentación, Granados no parece tomar en cuenta la diferencia que existe entre las llamadas «potencias intrínsecas»y «potencias extrínsecas» de un ente ${ }^{77}$, y de allí que no vea un evento en la totipotencialidad. Las "potencias intrínsecas» implican la capacidad de dicho ente para llevar a cabo su evolución natural, las potencias -instrucciones y energía- que en sí mismo ya contiene: la bellota, en condiciones normales, sin mediar intervención externa, sigue desde y por sí misma un curso de desarrollo que la convierte en roble. La llamada «potencia extrínseca», en cambio, supone que algún ente en concreto podría llegar a ser otra cosa pero sólo si es intervenido desde fuera y se interrumpe su desarrollo natural: un roble puede llegar a ser una mesa, pero sólo si un leñador lo corta y un carpintero une las tablas fabricando esa mesa. En sí mismo, si se lo deja seguir con su movimiento natural o curso de desarrollo en dirección a su fin (telos), el roble jamás será mesa.

77 Cf. M. A. Carrasco, Problemas Contemporáneos de Antropología y Bioética, Instituto de Estudios de la Sociedad, Chile, 2009, pp. 152-155. 
Pues bien, cuando Granados afirma que la totipotencialidad en la que culmina el proceso de des-diferenciación de la célula somática y la diferenciación que desde de allí comienza no marca un quiebre en el proceso, un cambio en la naturaleza de la célula, posiblemente entienda que sólo hay eventos capaces de cambiar la naturaleza de un ente si es que éstos son «producidos» desde fuera (potencia extrínseca). De ahí concluiría que la célula producida por SCNT debe contener desde el principio las potencias intrínsecas de un embrión humano. Este argumento, sin embargo, ya lo descartamos con el ejemplo de la muerte: un organismo cambia su naturaleza -por así decir- o deja de ser lo que era sin mediación de intervención externa: existe un evento que inicia un proceso (la des-composición) del todo distinto al del organismo, y que hace que el organismo deje de ser tal. Esto sería lo que significa un cambio sustancial: la pérdida de una forma y la adquisición de otra. ¿Pero cómo se adquiere una forma o cómo es que una forma llega a informar determinada materia para constituir una sustancia (i. e. un organismo humano)? De acuerdo con Aristóteles, en los artefactos el técnico fabrica un objeto -le «da su forma»- uniendo los materiales apropiados (madera y hierro para el serrucho, por ejemplo). Y en los objetos naturales la forma se transmite vía generación, es decir, «un objeto viene a la existencia a partir de la acción de otro objeto de la misma especie... que le transmite su forma» ${ }^{78}$. Ahora bien, ninguna de estas dos vías es aplicable al organismo artificialmente producido vía SCNT. La metafísica aristotélica es insuficiente en este caso; y, por ahora, parecería no haber una respuesta satisfactoria.

Sin embargo, la filosofía de Aristóteles sí explica en qué consiste propiamente la «forma» de los entes, y eso sí basta para el objetivo de este debate. En los artefactos, la «forma» es su función, la que les viene impuesta desde fuera, desde el diseño del artesano; y su relación con la materia es, como hemos dicho, extrínseca. Y en los entes vivos naturales, que precisamente no tienen una función dada de modo extrínseco, su función específica es la actualización y despliegue de aquellas potencialidades que están vinculadas con sus propiedades esenciales. De aquí se sigue que es posible reconocer la forma de un ente natural según la actualización de sus potencias o su comportamiento como tal. La des-diferenciación de

78 A. Vigo, Aristóteles..., p. 76. Y agrega «Como Aristóteles enfatiza reiteradamente, es un hombre lo que engendra a otro hombre, a diferencia de los artefactos que no proceden de artefactos de la misma especie (cf. p. ej. Fís. II 1 193b8)». 
la que es objeto el núcleo insertado vía SCNT es, por sí misma, prueba suficiente de que esa célula no es un organismo bumano.

Por otro lado, las sustancias tienen un sustrato material que se mantiene idéntico a través de sus cambios ${ }^{79}$; pero ese sustrato material no se identifica con el sujeto ontológico puesto que, entre las posibilidades de «cambios» que clasifica Aristóteles, está también el «cambio sustancial», los procesos de generación y corrupción (cf. Fís 190b3-10). En estos casos el sustrato también debe permanecer a lo largo del proceso, pues de otro modo las cosas surgirían «de la nada». Y en los seres vivos no resulta tan difícil de explicar la permanencia del sustrato ya que es incluso posible percibir las partes materiales que preexisten o sobreviven al objeto en cuestión (por ejemplo la materia que constituye al cadáver es, en principio, la misma que constituía al ser vivo, aunque obviamente comienza a desorganizarse, no cumplir funciones, etc. ${ }^{80}$. De aquí que no sea evidente, desde ninguna perspectiva, que el único evento capaz de producir un cambio sustancial y por ello un organismo humano sea la fusión del núcleo diferenciado y el ovocito enucleado, como afirma Granados. En la SCNT se constituye un sustrato material, pero su «forma» es un tema diferente.

Los defensores de la ANT-OAR, a pesar de no decirlo con claridad, afirmarían -contra Granados- que en una SCNT existen dos procesos distintos orientados a distintos fines, de lo que es posible inferir que ambos entes (la célula previa a la totipotencialidad y la que comienza la embriogénesis tras alcanzar ese estado) poseen una naturaleza diferente: el primero no es un organismo humano, mientras que el segundo sí lo es.

Esquemáticamente, se podría resumir así: (a) el primer proceso consiste en la des-diferenciación del núcleo de una célula artificialmente producida, orientado a alcanzar el estado propio del cigoto; este proceso sería condición necesaria para la aparición del organismo humano, pero no sería una fase del desarrollo de éste (tal como el acercamiento de los espermios a un óvulo es condición de la fecundación, pero no es una fase del desarrollo del embrión ${ }^{81}$ ). Y luego, en segundo lugar, (b) el proceso

79 La materia (lo meramente físico) que constituye a un perro, por ejemplo, no cambia cuando éste se mueve de un lado a otro. Podrá haber cambios locales, funcionales, etc.; pero la materia sigue siendo la misma.

80 Cf. A. Vigo, Aristóteles..., pp. 71-72.

81 Obviamente, ambos procesos son distintos, pero sí son análogos en cuanto «condición de posibilidad» de la generación de un individuo humano. El espermatozoide, se podría decir, tiene la potencia intrínseca de penetrar un óvulo; pero no de llegar a 
de desarrollo del cigoto cuyo telos es un adulto de naturaleza humana, el desarrollo del organismo humano.

La «teleología natural» ${ }^{82}$ de la célula creada por la SCNT (su dirección de desarrollo de acuerdo con sus potencias), por tanto, es la des-diferenciación o des-programación del núcleo insertado en el citoplasma. Este proceso llega a término cuando ese fin se completa: cuando se ha borrado completamente la identidad original de la célula alcanzando el estado de una célula totipotencial. Ése es un evento, el momento en el que se alcanza la meta hacia la que esa célula tendía. Después de este momento, se da «comienzo absoluto» a un desarrollo en otra dirección, totalmente inversa a la primera. Esto implica, a todas luces, la desaparición de una naturaleza (que se puede identificar de acuerdo a su teleología, igual en todos los ejemplares de una especie) y su transformación en otra. En este caso, en un embrión.

Por consiguiente, la teleología natural de un ser vivo está directamente relacionada con sus potencias intrínsecas, que están ya presentes inmanentemente y desde el principio en su naturaleza; y que constituyen esas virtualidades las que irá actualizando en su proceso de desarrollo en vistas a alcanzar su telos, su plenitud. De aquí se sigue que, en su inicio, un organismo debe poseer ya en sí todas sus potencias intrínsecas puesto que desde ése, su «comienzo absoluto», empieza el proceso de crecimiento continuo y gradual hasta convertirse en un ejemplar adulto de su especie. Ésta podría ser, a nuestro juicio, una primera clave para dar un marco de referencia

ser un nuevo organismo. De hecho, tras su unión con el óvulo, el espermio deja de ser un espermio y su «materia» (sólo los componentes materiales que lo constituían puesto que la «forma» la perdió al penetrar el óvulo y dejar por tanto de ser un espermio) pasa a formar parte de una nueva entidad (un cigoto) que sí tiene la potencia intrínseca de ser un adulto normal. Según esta analogía, la célula creada por SCNT tiene la potencia intrínseca de llegar a la totipotencialidad; pero no la de ser un adulto normal de la especie humana porque, al llegar a ese estado, esa célula cumple su telos y deja de existir.

Hay, sin embargo, ciertos autores contemporáneos (como, por ejemplo, Peter Singer) que, sin reconocer en el embrión a una persona, intentan hacer una reducción al absurdo diciendo que si éste lo fuera, los espermios y óvulos también lo serían (cf. P. Singer, Ética Práctica, Cambridge University Press, 2da ed., trad. Rafael Herrera, pp. 197-198). Pero claramente su argumentación carece de toda plausibilidad.

82 En rigor, en un artefacto no correspondería hablar de «teleología natural», pero usamos este término con el exclusivo propósito de resaltar el contraste con la embriogénesis. 
filosófico que permita acercarse, al menos en la teoría, a reconocer cuándo se está en presencia de un organismo humano unicelular ${ }^{83}$.

Un segundo punto es que si esa célula contiene en sí todas las potencias intrínsecas para el desarrollo de un organismo determinado, esa célula debe, necesariamente, ser totipotencial. Entonces, para que una célula única pueda considerarse un organismo humano tiene que contener ya en sí todo el organismo, es decir, tener en potencia cada fase del desarrollo propio del ser humano que se irá desplegando a lo largo del tiempo. Es decir, es condición de posibilidad de la existencia de un organismo que éste comience su carrera biológica a partir de una célula totipotencial; sólo ésta da cuenta del posterior actualizarse sucesiva y gradualmente de todas las potencias hasta llegar a la plenitud orgánica. «Antes» de la totipotencialidad, una célula no podría considerarse un organismo ${ }^{84}$.

Tercero, la célula creada por SCNT, como vimos, no tiene de inmediato la potencia para desarrollarse como un adulto normal de la especie humana ${ }^{85}$. Aunque es una célula que se mueve desde sí misma, la dirección de ese movimiento no es la propia de los organismos humanos. No tiene «forma» humana. Y todavía más importante, la célula producida por SCNT, antes

83 En realidad, lo que se podría y busca reconocer es cuando no se está en presencia de uno. Ya han empezado a surgir aplicaciones prácticas para este criterio, como es el ejemplo de Yamanaka (op. cit.); y como podría ser el de la ANT-OAR en caso de que se comprobara empíricamente y con la mayor certeza que la alteración epigenética impide que la célula alcance la totipotencialidad.

${ }^{84}$ Si esa (única) célula tuviera cualquier grado de especialización, incluso si es que estuviera cursando un proceso de des-diferenciación, no es un organismo porque no es totipotencial.

85 WaLKer ha argumentado que sí la tiene en cuanto tiene capacidad de automovimiento. Sin embargo, el automovimiento es lo que caracteriza a un «ser vivo», pero la dirección de ese automovimiento (su teleología, el fin al que su desarrollo se dirige) es la que indica la naturaleza de ese ser. Walker, al decir que la ANT no evita la antropogénesis, arguye que la nueva entidad mantiene «al menos algo de la espontaneidad innata que caracteriza al conceptus humano ordinario» («The Primacy of the Organism. A Response to Nicanor Austriaco», Communio: International Catholic Review 32 (2005), pp. 177-187: p. 180). HurlBut, en cambio, señala que los subsistemas orgánicos parciales (como células, tejidos...) que son componentes del todo, cuando se separan o son producidas separadamente del organismo, pueden temporalmente prolongar su desarrollo. Sin embargo, sin la autoregulación y coordinación coherente del organismo completo no son más que estructuras celulares fragmentarias, cuya trayectoria de crecimiento es distinta de la del embrión. (Cf. «Seeking Consensus: A Clarification and defense of Altered Nuclear Transfer», Hastings Center Report (Sept.Oct 2006): p. 3). 
de completar su desarrollo, no es totipotencial, lo que hace imposible que se identifique con un organismo puesto que no «alberga -como ya hemos citado- todas las instrucciones necesarias para constituir el cuerpo humano, que contiene alrededor de 100 trillones $\left(10^{14}\right)$ de células».

Finalmente, cuando se discutió acerca de qué determinaba la naturaleza de una célula, los oponentes a la ANT-OAR señalaron que, si bien la epigenética puede determinar la identidad de las células somáticas, un embrión unicelular no es lo mismo que cualquier célula. Las primeras son, precisamente, células diferenciadas; mientras que el segundo, en su totipotencialidad, las contiene en potencia a todas: es un organismo. El embrión no es sólo el sustrato de las determinaciones epigenéticas sino su fuente activa, la causa primera de éstas ${ }^{86}$. La epigenética no puede ser constitutiva sino sólo la manifestación fenoménica de una célula cuya identidad ontológica o sustancial ya está dada por el organismo, que es la causa primera de su diferenciación.

Y esto es así. Pero como dijo Brugger, si bien el estado epigenético no es constitutivo, sí es condición necesaria para la actualización de la vida embrionaria ${ }^{87}$ y señal cierta del estado de totipotencialidad que se asocia al cigoto. En este sentido, añadimos nosotros, la epigenética sí da un criterio para determinar cuándo se está frente a un nuevo organismo. Aunque el organismo sea ontológicamente previo a su actividad, es cronológicamente simultáneo, por lo que sí es un signo adecuado de identificación. Y aunque la célula no sea más que el sustrato de su estado epigenético (como una nariz de su chatura), y aunque tal estado esté determinado por el organismo entero y no por cada célula en particular; en el embrión unicelular esa célula es sustrato de su estado epigenético pero, a la vez, siendo ella todo el organismo, es también causa del mismo.

En conclusión, a pesar de que se dispute el «cómo llegó a ser organismo», lo que sí está claro es que en el organismo humano unicelular la epigenética sirve -como en toda célula- para reconocer «qué tipo de célula es»; y, al mostrar que es una célula totipotencial, también da la señal cierta de que es un organismo humano (o al contrario, si no es totipotencial, no es un organismo o embrión humano y podría, en principio, utilizarse para la investigación).

\footnotetext{
86 A. Walker, «The Primacy...», p. 179.

87 C. Brugger, «ANT-OAR: A Morally...», p. 758.
} 


\subsection{Criterios de identificación}

Comenzamos este trabajo presentando los cinco criterios más relevantes que hasta el momento se han dado para identificar al organismo humano unicelular producido artificialmente, resaltando que con los avances biotecnológicos contemporáneos ésta se ha vuelto una tarea urgente para la bioética. Los criterios eran: el momento de la fusión del núcleo de la célula somática con el óvulo enucleado en el caso de la SCNT, que se pretendía análogo a la fecundación; la posesión de un genoma humano razonablemente completo; la procedencia del ente vivo generado; el estado epigenético del cigoto, y la capacidad de expresarse como organismo y de desarrollo autodirigido. Nuestro instrumento de análisis fue el debate respecto de la ANT-OAR, una técnica que eventualmente podría producir CME sin destruir embriones. Un grupo de autores planteaba que el organismo humano se constituía en el momento mismo de la fusión en la SCNT y que cualquier intervención epigenética sólo producía embriones defectuosos; y otro grupo se inclinaba por la postura de que sólo existía organismo humano desde el momento en que el proceso de des-diferenciación en la SCNT alcanzaba el estado de una célula totipotencial.

A lo largo del debate, y en términos generales, los tres primeros criterios fueron refutados por la información científica. Algunos de ellos podrán ser complementarios a otros índices, pero ninguno es suficiente por sí mismo. Los dos criterios restantes, sin embargo, son más complejos de analizar, y es necesario recurrir a principios filosóficos para complementar la información empírica existente. En vistas a establecer la plausibilidad del cuarto criterio -el estado epigenético- la pregunta debió retrotraerse desde el ámbito físico al metafísico: qué determina la naturaleza de un ser. La prioridad ontológica de la célula frente a su estado epigenético fue el argumento básico de quienes defendían la existencia de un organismo desde la fusión. Esta prioridad, como en la discusión se fue reconociendo, es innegable, como la de la nariz sobre su chatura. Sin embargo, y éste fue nuestro punto, es igual de innegable el hecho de que es imposible la existencia una nariz sin chatura (o cualquier forma que se quiera). En otras palabras, no existe nariz antes de ser chata; lo que en nuestra analogía significaría que no existe organismo unicelular antes de estar en el estado epigenético asociado a la totipotencialidad. La prioridad ontológica de la nariz no es una prioridad cronológica. Nariz y chatura son simultáneas, i.e. sólo es posible decir que existe una nariz cuando ésta ya es chata. Este cuarto criterio, por tanto, bastaría, en primera instancia, para las decisiones que con urgencia debe 
tomar la bioética actual. A pesar de que el estado epigenético, en cuanto es un «estado» de la célula, pudiera considerarse accidental a la misma, en el cigoto unicelular éste sería «el» accidente que evidenciaría su existencia.

Ahora bien, esta defensa del criterio de la epigenética, que hacemos nuestra, debe justificarse frente a las objeciones que puedan surgir. En primer término, aquí se han buscado señales, indicadores, signos por los que se pueda reconocer la presencia de un organismo humano unicelular producido por un medio diverso de la fecundación; y no se está discutiendo el cómo se constituye este organismo. Por ello bastó con indicar que aunque ontológicamente posterior, la epigenética es cronológicamente simultánea a esa constitución. Eso es suficiente para que pueda ser una señal cierta.

Una segunda objeción obvia es que aunque todo lo expuesto sea verdadero, el gran problema es que la ciencia no ha descubierto aún marcadores biológicos precisos y suficientes para conocer el estado epigenético de una célula totipotencial ${ }^{88}$. Por ahora sólo hay certezas a posteriori, tras conocer el comportamiento de las células. Así también pasó con Dolly: al comienzo no se sabía si el resultado de la SCNT podría ser un nuevo organismo; no se sabía si un núcleo especializado transferido a un óvulo enucleado sería capaz de «regresar» hasta el estado de totipotencialidad requerido para la constitución de éste. Sólo hubo una demostración fehaciente de que con la SCNT sí se podía producir artificialmente un nuevo organismo tras el desarrollo de un adulto normal de la especie. Esta insuficiencia en el conocimiento científico, entonces, esta incapacidad de conocer el estado epigenético de la célula antes de su desarrollo, imposibilita, en principio, la experimentación (a través de la SCNT) con CME humanas, al menos hasta que se descubra cómo reconocer su estado epigenético actual.

Sin embargo la filosofía, mirando el mismo fenómeno pero desde otra perspectiva, puede suplir parcialmente esta insuficiencia. Más que buscar un criterio cierto para identificar al organismo humano unicelular producido por SCNT, la reflexión filosófica puede dar un marco de referencia

88 En el caso de las células pluripotenciales sí se ha descubierto un patrón de expresión génica bastante típico. Sin embargo, el test último sigue siendo el comportamiento de la célula, tal como se describió antes con el experimento que resultó en la producción de ratones quimera. 
para orientarse en esta búsqueda y en las decisiones bioéticas que en la actualidad resulta imprescindible tomar.

Antes de descubrir los marcadores que muestren el estado epigenético de una célula ya sabemos, a través de la reflexión filosófica, que sólo la célula humana totipotencial puede considerarse un organismo, porque sólo ella contiene en sí las potencias intrínsecas que corresponderían a lo que metafóricamente se ha llamado «instrucciones» o «plan inmanente»para su desarrollo. Esas potencias marcarán la teleología natural de la célula en cuestión, y sólo si ésta va pasando por las fases (o algunas fases al menos) de la embriogénesis humana, es posible afirmar que se está en presencia de un organismo humano. Si esa dirección de desarrollo es totalmente distinta, o incluso contraria, a la del embrión humano normal, se puede afirmar con certeza que esa célula no es un organismo humano, una persona.

$Y$ éste, que fue el problema original del debate acerca de la legitimidad de la ANT-OAR, puede entonces quedar zanjado incluso antes de disponer de toda la información científica requerida. Si hay certeza lógica de que sólo hay organismo cuando una célula es totipotencial, la inserción de un núcleo especializado en el ovocito enucleado no puede, por definición, ser organismo. El único obstáculo sería no saber si ese núcleo se des-diferencia de modo instantáneo, lo que generaría desde el inicio una célula totipotencial. Sin embargo, en esto la ciencia ya ha probado que tal des-diferenciación es un proceso, que lleva tiempo, por lo que esa célula artificial no es organismo hasta alcanzar el fin de este proceso, la totipotencialidad. Todavía más, si al concluir el proceso de des-diferenciación esa célula comienza con otro completamente análogo a la embriogénesis natural, puede afirmarse con igual certeza que, tras la culminación del primer proceso esa célula cambia su naturaleza, se convierte en «otra cosa»; y en este caso específico en un organismo humano: una persona. Basta conocer el «obrar» de esa célula, puesto que dado nuestro horizonte cognoscitivo no nos será nunca posible identificar directamente su «sen». Entonces si esa célula «obra» como los otros organismos de la especie humana, al menos en alguna fase de su desarrollo, es posible decir que efectivamente pertenece a nuestra especie y que debe ser tratada como tal. Pero si no lo hace en ningún momento, no puede, por definición, ser un organismo humano ${ }^{89}$.

89 De todo lo anterior se sigue que, a pesar de no contar con las pruebas empíricas suficientes, sí podría afirmarse que -aplicando siempre el principio de cautela- los proponentes de la ANT-OAR estarían en lo correcto: en caso de que por alguna 
Del quinto criterio señalado en un comienzo para reconocer a un organismo humano unicelular («la capacidad de expresarse como organismo y de desarrollo autodirigido») no hemos dicho nada; pero éste sí ha estado implícito en toda nuestra argumentación. Un problema grave que se le puede adjudicar a este criterio es, precisamente, la imposibilidad para aplicarlo en el organismo humano unicelular antes de que su desarrollo sea perceptible. Empíricamente, por tanto, tampoco es satisfactorio. Pero en él sí están implícitas las dos características que hemos subrayado como esenciales para dar el marco de referencia que la bioética contemporánea requiere en vistas a ciertos juicios urgentes: las potencias intrínsecas y la teleología. Para que una célula pueda considerarse ya un organismo debe contener en sí las potencias propias de su especie que son, a su vez, las que marcarán su teleología. En la medida en que esas potencias se vayan actualizando, lo que equivale a las diversas fases de su desarrollo, el todo orgánico multicelular se irá estructurando.

Según afirma Juan de Dios Vial Correa, dando mayor claridad a esta idea, una de las notas fundamentales de todo organismo es que «sigue un camino "robusto" y prescrito por la especie: o sea su estado en cualquier instante de su vida puede ser predicho con razonable exactitud y el trayecto es regulado contra perturbaciones externas» ${ }^{90}$. Bajo esta descripción empírica se esconde el concepto filosófico de teleología, en cuanto el camino «prescrito por la especie» ha de moverse en una dirección particular hacia algún fin (o telos). Asimismo, el movimiento, para ser predecible, debe ser el actualizarse paulatino de las potencias intrínsecas propias de su naturaleza, que ya es conocida por observaciones anteriores.

\section{Consideraciones finales}

Concluyendo ya con este trabajo hemos visto que desde la mera ciencia aún no es posible encontrar un criterio aplicable a priori para identificar a

alteración epigenética previa a la SCNT se pudiese detener el proceso de la des-diferenciación del núcleo somático introducido, sobreactivando, por ejemplo, un gen comprobadamente incompatible con la totipotencialidad (como el NANOG), sería posible producir CME sin riesgo de crear y luego desechar personas.

90 Esto no significa que no sea influido por el ambiente, sino que continúa su camino de desarrollo de acuerdo con sus potencias intrínsecas. La segunda nota fundamental de todo organismo que el autor menciona es que «la evolución de estos caminos de desarrollo tiene lugar dentro de un espacio delimitado físicamente». Cf. J. CorreA, «Conferencia dictada en la Pontificia Universidad Católica de Chile», en Ars Medica vol. 4, n 6, 2002. 
un organismo humano unicelular producido artificialmente por medio de técnicas distintas a la fecundación (clonación u otros). Pero la información empírica, junto con la reflexión filosófica, sí pueden dar un marco de referencia orientativo para este problema tan urgente en nuestros días. A nuestro entender, los conceptos fundamentales para éste son los de potencias intrínsecas y teleología; los cuales, al menos en primera instancia, sí dan luces respecto de qué aspectos son los que en primer lugar se deben tomar en cuenta antes de emitir juicios relativos a la intervención en células que podrían ser organismos humanos en sus primerísimos estadios de vida.

La filosofía, a través de un razonamiento analítico, puede establecer plausiblemente cuáles son los criterios descriptivos más relevantes y en los que la investigación científica debería profundizar. Por otro lado, y aunque salvando sus diferencias esenciales, aquí también hemos visto como los conceptos filosóficos, a veces en apariencia tan abstractos, tienen sus correlatos empíricos; y de este modo son capaces de «penetrar» en la ciencia y, en algunos casos, clarificar ciertos problemas. Por ejemplo, la simultaneidad de la genética y la epigenética, como la de la nariz y su chatura, que hace absurda la oposición entre ambas; o el establecer que sólo una célula totipotencial puede considerarse un organismo, aquel que seguirá el camino robusto (la teleología) propia de su especie.

De este modo nos ha sido posible no sólo proponer un primer esbozo de marco orientativo para las decisiones bioéticas relativas al embrión humano unicelular producido por una vía distinta a la fecundación -mostrando a su vez que los criterios ciertos o exactos están aún fuera de nuestro alcance-; sino también hemos podido evidenciar cómo la ciencia y la filosofía deben ir de la mano en la bioética, iluminándose mutuamente, puesto que, aunque desde perspectivas distintas, se refieren, en última instancia, a una misma y única realidad.

Y esta realidad, el respeto por la vida y la dignidad de la persona humana desde su concepción, adquiere además una trascendencia absoluta a la luz de la Fe. Cuando la bioética incluye la perspectiva teológica, los problemas relativos a la persona humana, y en este caso a la eventual producción artificial y manipulación de una persona, imagen de Dios Uno y Trino, resulta imprescindible clarificar, tomar posición y dar orientaciones inmediatas si es que estos procedimientos se realizan ya en el mundo. Monseñor Fernando Chomali, con toda claridad, expresa: «Para 
los creyentes en Dios, todo lo que existe tiene su fundamento en Dios creador y adquiere el estatuto de regalo, de don y de algo gratuito. Dios es el principio de todo cuanto existe, puesto que hace surgir el ser desde el no ser, es decir, desde la nada. Desde esta perspectiva del don, se entiende que el sentido último no proviene de sí mismo sino de aquel que lo creó, por lo que podemos concluir que los hombres no crean, sólo descubren lo que existe y lo transforman en la medida de sus necesidades y capacidades. ... De esta forma, el hombre creyente es custodio, guardián, administrador y continuador de la creación y de la realidad donada por Dios, a través de su trabajo y su capacidad de engendrar vida, pero desde ningún punto de vista es su dueño o patrón» ${ }^{91}$.

Por esta misma razón, Benedicto XVI afirma que vulnerar la integridad o poner en peligro la vida de un ser humano -aunque sea unicelular- no sólo atenta contra él mismo sino también contra su Creador y Redentor. Cada persona, incluyendo aquella que pueda ser un producto artificial fabricado en un laboratorio, es en última instancia creada por Dios, quien le infunde directamente su alma única. Y aunque no existe Revelación explícita sobre el momento en que se inicia la vida, sí sabemos que en el momento de la Anunciación el Verbo de Dios «se hizo carne» (Jn 1, 14), y que -como dice el Papa- «San Lucas, al narrar el encuentro de la Madre de Jesús, que lo había concebido en su seno virginal hacía sólo pocos días, con la madre de Juan Bautista, ya al sexto mes de embarazo, testimonia la presencia activa, aunque escondida, de dos niños $»^{92}$; de lo que podemos plausiblemente inferir que al asumir nuestra naturaleza humana el Hijo de Dios también comenzó siendo un «cigoto», por lo que no puede excluir de su acción y Pasión redentora a ninguno de sus hermanos en la carne, entre los que se cuentan los embriones artificialmente producidos. De aquí la claridad y fuerza de las palabras de Benedicto XVI:

«El amor de Dios no hace diferencia entre el recién concebido, aún en el seno de su madre, y el niño o el joven o el hombre maduro o el anciano. No hace diferencia, porque en cada uno de ellos ve la huella de su imagen y semejanza (cf. Gn 1,26). No hace diferencia, porque en todos ve reflejado el rostro de su Hijo unigénito, en quien "nos ha elegido antes de la creación del mundo (...), eligiéndonos de antemano para ser

\footnotetext{
91 Cf. F. Chomal, Bioética... pp. 39-40. Énfasis nuestro.

92 Benedicto XVI, Discurso a la Pontificia Academia para la Vida, 27 de febrero de 2007.
} 
sus hijos adoptivos (...), según el beneplácito de su voluntad" (Ef 1, 46). Este amor ilimitado y casi incomprensible de Dios al hombre revela hasta qué punto la persona humana es digna de ser amada por sí misma, independientemente de cualquier otra consideración: inteligencia, belleza, salud, juventud, integridad, etc. En definitiva, la vida humana siempre es un bien, puesto que "es manifestación de Dios en el mundo, signo de su presencia, resplandor de su gloria" (Evangelium Vitae, 34)».

Por consiguiente, la perspectiva teológica realza la importancia de nuestra discusión y la urgencia de este estudio, ya que si el amor de Dios «no hace diferencia» y es «independiente de cualquier consideración», el organismo humano unicelular producido artificialmente no sólo es persona, hija de Dios, sino que es también la más vulnerable, maltratada desde incluso antes de su «producción», cosificada y convertida en artefacto; al tiempo que, como cualquier otra persona de cualquier otra condición, sigue siendo, de un modo difícil de imaginar pero que es esencial comprender para hacer respectar, el reflejo mismo Su Rostro. 
Resumen: en las últimas décadas la bioética se ha vuelto un tema crucial para la Iglesia. La dinámica propia de la técnica, que se auto-propulsa y avanza con independencia de criterios éticos, amenaza de modo inminente la dignidad humana. En la actualidad ya existe la posibilidad de producir artificialmente seres humanos, incluso sin la mediación de gametos. Pero lo que no existe son los índices para reconocer cuándo una célula intervenida sigue siendo sólo una célula -eventualmente pluripotencial y por tanto con grandes promesas terapéuticas; o cuando ya es una célula totipotencial, un cigoto, un organismo humano: una persona. Ciencia, filosofía y teología, como se mostrará en este artículo, se unen en la reflexión bioética para encontrar de modo urgente esas señales; puesto que la biotecnología sigue avanzando, y hay de tomar posición sobre sus descubrimientos. La Iglesia no puede callar frente a una posible producción artificial, instrumentalización y destrucción de personas; que aunque estén en su fase unicelular y hayan llegado al mundo como artefactos, siguen siempre siendo el reflejo del Rostro de Dios.

Palabras clave: bioética; biotecnología; organismo; persona; células madres; transferencia nuclear; inicio de la vida.

Abstract. In recent decades, bioethics has become a crucial issue for the church. The dynamics of such study, which is self-propelled and advances independently of ethical criteria, is imminently threatening to human dignity. It is now possible to artificially produce human beings, even without the involvement of gametes. What still hasn't been established is an index that recognizes when a manipulated cell is still a cell -eventually pluripotent and therefore possessing great therapeutic promise- or when it has become a totipotent cell, a zygote, a human organism, namely a person. Science, philosophy and technology, as is shown in this paper, come together to reflect on bioethics in the urgent need to find these signs, given that biotechnology is still advancing and a position must be taken on its discoveries. The Church cannot remain silent as it beholds possible artificial production, instrumentalization and destruction of people who, despite being in the single-cell phase and having come to the world as artifacts, are still reflections of the face of God.

Key words: bioethics, biotechnology, organism, person, stem cells, nuclear transfer, beginning of life. 